\title{
Mechanistic Implications of Nickel-Catalyzed Reductive Coupling of Aldehydes and Chiral 1,6-Enynes
}

\author{
Ryan M. Moslin, Timothy F. Jamison.* \\ Department of Chemistry, Massachusetts Institute of Technology, Cambridge, \\ Massachusetts, 02139
}

\section{General Methods}

Unless otherwise noted, all reactions were performed under an oxygen-free atmosphere of argon using standard Schlenk-line techniques. Bis(cyclooctadienyl)nickel $(0)\left(\mathrm{Ni}(\mathrm{cod})_{2}\right)$, and tricyclopentylphosphine $\left(\mathrm{PCyp}_{3}\right)$ were purchased from Strem Chemicals, Inc. and used without furthur purification. Triethylborane $\left(\mathrm{Et}_{3} \mathrm{~B}\right)$, triethylamine, methylsulfoxide, tributylphosphine $\left(\mathrm{PBu}_{3}\right)$, and penten-3-ol were purchased from Aldrich Chemical Co. and, unless otherwise stated, used as received.

Isobutyraldehyde (Alfa Aeser) was distilled from anhydrous magnesium sulfate $\left(\mathrm{MgSO}_{4}\right)$ prior to use. Diisopropylamine was distilled from calcium hydride and stored over potassium hydroxide. ( $( \pm$ )-4,4-dimethyl-penten-3-ol was synthesized according to literature procedure, and distilled prior to use. ${ }^{1}$ Tetrahydrofuran (THF) and diethyl ether were freshly distilled over sodium/benzophenone ketyl, and dichloromethane (DCM) was freshly distilled from calcium hydride.

${ }^{1} \mathrm{H}$ NMR was performed on a $500 \mathrm{MHz}$ Varian instrument, ${ }^{13} \mathrm{C}$ NMR was performed on a $500 \mathrm{MHz}$ Varian instrument equipped with an inverse probe, and in all cases the solvent was deuterochloroform $\left(\mathrm{CDCl}_{3}\right)$ which had been filtered through activated basic alumina prior to use. Infrared (IR) spectra were recorded as a thin film between $\mathrm{NaCl}$ plates on a Perkin-Elmer Model 2000 FT-IR System transform spectrometer. High resolution mass spectra (HRMS) were obtained on a Bruker Daltonics 
APEXII 3 Tesla Fourier Transform Mass Spectrometer by the Massachusetts Institute of Technology Department of Chemistry Facility.

(+)-Penten-3-ol: Synthesized according to the literature. ${ }^{2}$ Flame-dried molecular sieves $4 \AA$ (c. $5 \mathrm{~g}$ ) were loaded into a $100 \mathrm{ml}$ round bottomed flask filled with DCM (25 $\mathrm{ml})$. To this suspension was added diisopropyl $D$-tartrate $(352 \mu \mathrm{l}, 2.1 \mathrm{mmol})$ and racemic penten-3-ol ( $3 \mathrm{~g}, 34 \mathrm{mmol})$. The suspension was cooled to $-5^{\circ} \mathrm{C}$ and $\mathrm{Ti}(\mathrm{O} i \mathrm{Pr})_{4}(414 \mu \mathrm{l}$, $1.4 \mathrm{mmol})$ was added. The reaction was stirred for 30 minutes, and then $t \mathrm{BuOOH}(5.5 \mathrm{M}$ in decanes, $6 \mathrm{~mL}, 33 \mathrm{mmol}$ ) was added. The reaction was warmed to $0{ }^{\circ} \mathrm{C}$ and stirred for 7 hours. The slurry was added to a solution of iron(II) sulfate $(11 \mathrm{~g})$ and citric acid $(3.5 \mathrm{~g})$ in water $(30 \mathrm{~mL})$ and diluted with ether $(80 \mathrm{~mL})$. The layers were separated and the aqueous layer extracted once with diethyl ether. The combined organics were washed with brine, dried over magnesium sulfate and filtered. Solvent was removed under atmospheric pressure via distillation through a Vigereux column $(10 \mathrm{~cm})$. Fractional distillation $\left(20\right.$ torr, $\left.50^{\circ} \mathrm{C}\right)$ of the residue then provided $(+)$-penten-3-ol as a clear oil $(1 \mathrm{~g}$, $33 \%$ yield $) .[\alpha]_{\mathrm{D}}+21.6\left(\mathrm{c} 0.37,22^{\circ} \mathrm{C}, \mathrm{CHCl}_{3}\right)$. The optical rotation was compared to literature values, ${ }^{3}$ and the stereocenter was determined to be $(S)$.

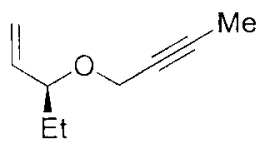

(-)-8: Sodium hydride $(7.5 \mathrm{~g}, \sim 58 \%, \sim 180 \mathrm{mmol})$ was loaded into a round bottom flask and rinsed with anhydrous pentanes $(3 \times 50 \mathrm{~mL})$ and dried in vacuo. THF (200 mL) was added followed by addition of $(+)$-penten-3-ol $(3.08 \mathrm{~mL}, 30 \mathrm{mmol})$, and the mixture was stirred for 3 hours at room temperature prior to addition of 1-bromo2-butyne $(5.25 \mathrm{~mL}, 60 \mathrm{mmol})$. After stirring overnight, the reaction was quenched by 
careful addition of saturated aqueous ammonium chloride. The organics were extracted with diethyl ether $(3 \times 150 \mathrm{~mL})$, washed with brine, dried over magnesium sulfate, filtered and concentrated $\left(0^{\circ} \mathrm{C}, 50\right.$ torr). The product (as a solution in THF) was loaded directly onto silica $(7 \mathrm{~cm} \times 5 \mathrm{~cm})$ and chromatographed (10:1 pentanes:diethyl ether). Removal of the solvent $\left(0{ }^{\circ} \mathrm{C}, 50\right.$ torr $)$ followed by distillation through a short path apparatus $\left(35^{\circ} \mathrm{C}, 1\right.$ torr) yielded (-)-8 as a clear oil $(3.83 \mathrm{~g}, 92 \%,>90 \% \mathrm{ee}) . \quad(-)-8:[\alpha]_{\mathrm{D}}-75.7^{\circ}(c 3.09$, $\mathrm{CHCl}_{3}, 22^{\circ} \mathrm{C}$ ); chiral $\mathrm{GC}$ analysis (Varian CP-3800, G-TA column, $50{ }^{\circ} \mathrm{C}, 0.7 \mathrm{ml} / \mathrm{min} \mathrm{H}_{2}$ carrier) $\mathrm{T}_{\mathrm{R}}(S) 14.4 \mathrm{~min}, \mathrm{~T}_{\mathrm{R}}(R) 14.9 \mathrm{~min}$; IR $2964(\mathrm{~m}), 2924(\mathrm{~s}), 2856(\mathrm{~m}), 2248(\mathrm{w})$, 1457 (b, w), 1057 (s), 910 (s) cm ${ }^{-1}$; 'H NMR (500 MHz, $\mathrm{CDCl}_{3}$ ) $\delta 5.63$ (ddd, J = 17.0, $11.0,8.5 \mathrm{~Hz}, 1 \mathrm{H}), 5.23(\mathrm{dd}, \mathrm{J}=8.5,2.0 \mathrm{~Hz}, 1 \mathrm{H}), 5.22(\mathrm{dd}, \mathrm{J}=17.0,2.0 \mathrm{~Hz}, 1 \mathrm{H}), 4.15(\mathrm{dq}$, $\left.\mathrm{J}_{\mathrm{d}}=15.0 \mathrm{~Hz}, \mathrm{~J}_{\mathrm{q}}=2.0 \mathrm{~Hz}, 1 \mathrm{H}\right), 3.97\left(\mathrm{dq}, \mathrm{J}_{\mathrm{d}}=15.0 \mathrm{~Hz}, \mathrm{~J}_{\mathrm{q}}=2.0 \mathrm{~Hz}, 1 \mathrm{H}\right), 3.73(\mathrm{q}, \mathrm{J}=7.0$ $\mathrm{Hz}, 1 \mathrm{H}), 1.86(\mathrm{t}, \mathrm{J}=2.0 \mathrm{~Hz}, 3 \mathrm{H}), 1.66$ (apparent septet, $\mathrm{J}=7.0 \mathrm{~Hz}, 1 \mathrm{H}), 1.52$ (apparent septet, $\mathrm{J}=7.0 \mathrm{~Hz}, 1 \mathrm{H}), 0.91(\mathrm{t}, \mathrm{J}=7.5 \mathrm{~Hz}, 3 \mathrm{H}),{ }^{13} \mathrm{C} \mathrm{NMR}\left(125.8 \mathrm{MHz} \mathrm{CDCl}_{3}\right) \delta 138.3$, $118.1,81.9,81.8,75.8,56.1,28.3,9.9,3.9$.

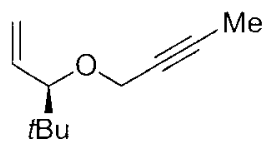

$( \pm)-9$ : According to the procedure for $8,( \pm)$-4,4-dimethyl-penten-3-ol $(1.71 \mathrm{~g}, 15 \mathrm{mmol})$ was reacted with $600 \mathrm{~mol} \% \mathrm{NaH}$ and $300 \mathrm{~mol} \% \mathrm{l}$-bromo-2-butyne to give $2 \mathrm{~g}(80 \%)$ of a clear oil after chromatography (25:1 pentanes:diethyl ether) and distillation $\left(65^{\circ} \mathrm{C}, 1\right.$ torr). 9: IR $2956(\mathrm{~s}), 2870(\mathrm{~m}), 2361(\mathrm{w}), 1464$ (b, w), $1363(\mathrm{~m})$, $1136(\mathrm{~m}) \mathrm{cm}^{-1} ;{ }^{1} \mathrm{H}$ NMR $\left(500 \mathrm{MHz}, \mathrm{CDCl}_{3}\right) \delta 5.68(\mathrm{ddd}, \mathrm{J}=17.0,10.5,8.5 \mathrm{~Hz}, 1 \mathrm{H}), 5.27$ $(\mathrm{dd}, \mathrm{J}=10.5,1.5 \mathrm{~Hz}, 1 \mathrm{H}), 5.19(\mathrm{dd}, \mathrm{J}=17.0,1.5 \mathrm{~Hz}, 1 \mathrm{H}), 4.14\left(\mathrm{dq}, \mathrm{J}_{\mathrm{d}}=15.0 \mathrm{~Hz}, \mathrm{~J}_{\mathrm{q}}=2.0\right.$ $\mathrm{Hz}, 1 \mathrm{H}), 3.92\left(\mathrm{dq}, \mathrm{J}_{\mathrm{d}}=15.0 \mathrm{~Hz}, \mathrm{~J}_{\mathrm{q}}=2.0 \mathrm{~Hz}, 1 \mathrm{H}\right), 3.42(\mathrm{~d}, \mathrm{~J}=8.5 \mathrm{~Hz}, 1 \mathrm{H}), 1.86(\mathrm{t}, \mathrm{J}=2.0$ 
$\mathrm{Hz}, 3 \mathrm{H}), 0.91(\mathrm{~s}, 9 \mathrm{H}) .{ }^{13} \mathrm{C} \mathrm{NMR}\left(125.8 \mathrm{MHz} \mathrm{CDCl}_{3}\right) \delta 135.4,119.2,88.0,81.5,76.1$, 56.4, 34.4, 26.3, 3.9; HRMS $m / z$ (ESI, $\mathrm{M}+\mathrm{Na}^{+}$) calcd 189.1250 found 189.1256.

\section{General procedure for nickel-catalyzed reductive coupling:}

In a glovebox, $\mathrm{Ni}(\mathrm{cod})_{2}(14 \mathrm{mg}, 0.05 \mathrm{mmol}, 10 \mathrm{~mol} \%)$ was added to a pre-dried $10 \mathrm{ml}$ round bottom flask, if phosphine was included it was added $(20 \mathrm{~mol} \%)$ at this time. The flask was then placed under Argon on a Schlenk line and neat $\mathrm{Et}_{3} \mathrm{~B}$ was added $(0.15 \mathrm{~mL}$, $1.0 \mathrm{mmol}, 200 \mathrm{~mol} \%)$. The solution was cooled to $0{ }^{\circ} \mathrm{C}$ and the $i \mathrm{PrCHO}(90 \mu \mathrm{L}, 1.0$ mmol, $200 \mathrm{~mol} \%$ ) was added dropwise. The reaction was stirred for 3 minutes and then the 1,6 -enyne $(0.5 \mathrm{mmol})$ was added in a single portion. The ice bath was allowed to warm to room temperature overnight. After 15 hours and the reactions were diluted with reagent grade EtOAc and then opened to the atmosphere and stirred for 30 minutes.

Solvent was removed in vacuo and crude material was purified via silica gel chromatographed.

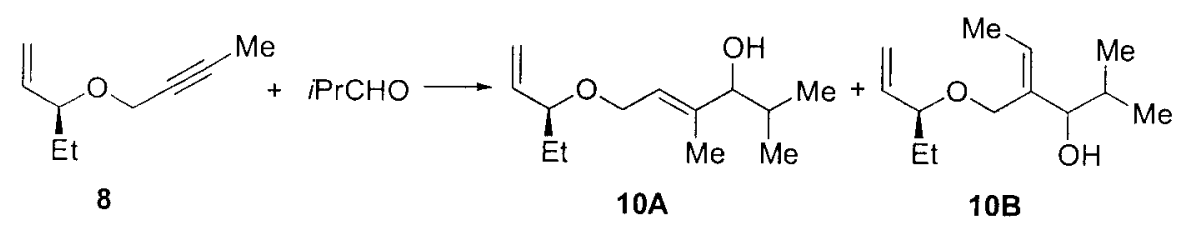

$8+i \mathrm{PrCHO}$.

no phosphine: $8(69 \mathrm{mg}, 0.5 \mathrm{mmol})$ was reacted with $i \operatorname{PrCHO}(90 \mu \mathrm{L}, 1.0 \mathrm{mmol})$ in the presence of $\mathrm{Ni}(\mathrm{cod})_{2}(14 \mathrm{mg}, 0.05 \mathrm{mmol})$ and $\mathrm{Et}_{3} \mathrm{~B}(0.15 \mathrm{~mL}, 1.0 \mathrm{mmol})$. Crude material was chromatographed with 15:1 hexanes:diethyl ether $\rightarrow 7: 1$ hexanes: ethyl acetate to give $59 \mathrm{mg}(56 \%)$ of $\mathbf{1 0 A}$ as a clear oil. $\mathrm{R}_{\mathrm{F}}=0.30(6: 1$ hexanes:EtOAc, $\mathrm{KMnO}_{4}$ ) (single regioisomer, 95:5 mixture of $S, R$ and $S, S$ ). $\mathrm{PCyp}_{3}: 8(69 \mathrm{mg}, 0.5 \mathrm{mmol})$ was reacted with $i \mathrm{PrCHO}(90 \mu \mathrm{L}, 1.0 \mathrm{mmol})$ in the presence of $\mathrm{Ni}(\mathrm{cod})_{2}(14 \mathrm{mg}, 0.05 \mathrm{mmol}), \mathrm{PCyp}_{3}(28 \mu \mathrm{L}, 0.1 \mathrm{mmol})$, and $\mathrm{Et}_{3} \mathrm{~B}$ 
$(0.15 \mathrm{~mL}, 1.0 \mathrm{mmol})$. Crude material was chromatographed with $15: 1$ hexanes:diethyl ether $\rightarrow$ 9:1 hexanes:ethyl acetate to give $25 \mathrm{mg}(24 \%)$ of $\mathbf{1 0 B}$ as a clear oil $\mathrm{R}_{\mathrm{F}}=0.46\left(6: 1\right.$ hexanes:EtOAc, $\mathrm{KMnO}_{4}$ ) (single regioisomer, 55:45 mixture of diastereomers).

$\mathrm{PBu}_{3}: 8$ (69 $\left.\mathrm{mg}, 0.5 \mathrm{mmol}\right)$ was reacted with $i \operatorname{PrCHO}(90 \mu \mathrm{L}, 1.0 \mathrm{mmol})$ in the presence of $\mathrm{Ni}(\operatorname{cod})_{2}(14 \mathrm{mg}, 0.05 \mathrm{mmol}), \mathrm{PBu}_{3}(25 \mu \mathrm{L}, 0.1 \mathrm{mmol})$, and $\mathrm{Et}_{3} \mathrm{~B}(0.15$ $\mathrm{mL}, 1.0 \mathrm{mmol}$ ). Crude material was chromatographed with $15: 1$ hexanes:diethyl ether $\rightarrow$ 9:1 hexanes:ethyl acetate to give $19.3 \mathrm{mg}(18 \%)$ of $\mathbf{1 0 A}$ and $16 \mathrm{mg}(15 \%)$ of 10B as clear oils (10A: 50:50 mixture of diastereomers; 10B: 55:45 mixture of diastereomers).

(R)-18: 8 (69 mg, $0.5 \mathrm{mmol})$ was reacted with $i \operatorname{PrCHO}(90 \mu \mathrm{L}, 1.0 \mathrm{mmol})$ in the presence of $\mathrm{Ni}(\mathrm{cod})_{2}(14 \mathrm{mg}, 0.05 \mathrm{mmol}),(R)-18(41 \mathrm{mg}, 0.1 \mathrm{mmol})$, and $\mathrm{Et}_{3} \mathrm{~B}$ $(0.15 \mathrm{~mL}, 1.0 \mathrm{mmol})$. Crude material was chromatographed with $15: 1$ hexanes:diethyl ether $\rightarrow$ 9:1 hexanes:ethyl acetate to give $9 \mathrm{mg}(8 \%)$ of $\mathbf{1 0 A}$ and $10 \mathrm{mg}(9 \%)$ of $10 \mathrm{~B}$ as clear oils $(\mathbf{1 0 A}: 30: 70$ mixture of $S, R: S, S ; \mathbf{1 0 B}: 72: 28$ mixture of diastereomers).

$(S)-18:^{4} 8$ (69 mg, $\left.0.5 \mathrm{mmol}\right)$ was reacted with $i \operatorname{PrCHO}(90 \mu \mathrm{L}, 1.0 \mathrm{mmol})$ in the presence of $\mathrm{Ni}(\mathrm{cod})_{2}(14 \mathrm{mg}, 0.05 \mathrm{mmol}),(S)-18(41 \mathrm{mg}, 0.1 \mathrm{mmol})$, and $\mathrm{Et}_{3} \mathrm{~B}$ $(0.15 \mathrm{~mL}, 1.0 \mathrm{mmol})$. Crude material was chromatographed with $15: 1$ hexanes:diethyl ether $\rightarrow$ 9:1 hexanes:ethyl acetate to give $10.6 \mathrm{mg}(10 \%)$ of $10 \mathrm{~A}$ and $8.9 \mathrm{mg}(9 \%)$ of $\mathbf{1 0 B}$ as clear oils (10A: 66:34 mixture of $S, R: S, S ; \mathbf{1 0 B}$ : 32:68 mixture of diastereomers).

$\mathrm{FcPPh}_{2}: 8(69 \mathrm{mg}, 0.5 \mathrm{mmol})$ was reacted with $i \mathrm{PrCHO}(90 \mu \mathrm{L}, 1.0 \mathrm{mmol})$ in the presence of $\mathrm{Ni}(\operatorname{cod})_{2}(14 \mathrm{mg}, 0.05 \mathrm{mmol}), \mathrm{FcPPh}_{2}(37 \mathrm{mg}, 0.1 \mathrm{mmol})$, and $\mathrm{Et}_{3} \mathrm{~B}$ 
$(0.15 \mathrm{~mL}, 1.0 \mathrm{mmol})$. Crude material was chromatographed with $15: 1$ hexanes:diethyl ether $\rightarrow$ 9:1 hexanes:ethyl acetate to give $8.2 \mathrm{mg}(7 \%)$ of $10 \mathrm{~A}$ and $7.2 \mathrm{mg}(6 \%)$ of $\mathbf{1 0 B}$ as clear oils (10A: $56: 44$ mixture of $S, R: S, S ; \mathbf{1 0 B}: 52: 48$ mixture of diastereomers).

10A: $[\alpha]_{\mathrm{D}}-23.4\left(\mathrm{c} 0.86, \mathrm{CHCl}_{3}, 22^{\circ} \mathrm{C}\right)$; IR $3429(\mathrm{~b}, \mathrm{~m}), 2962(\mathrm{~s}), 2934(\mathrm{~s}), 2872(\mathrm{~s})$, $1465(\mathrm{~m}), 1094$ (s), 1017 (s); ${ }^{1} \mathrm{H}$ NMR (500 MHz, $\left.\mathrm{CDCl}_{3}\right)$-data is for $S, R$ diastereomer- $\delta 5.68(\mathrm{ddd}, \mathrm{J}=17.0,10.5,8.0 \mathrm{~Hz}, 1 \mathrm{H}), 5.55(\mathrm{t}, \mathrm{J}=6.0 \mathrm{~Hz}, 1 \mathrm{H})$, $5.20(\mathrm{dd}, \mathrm{J}=10.5,1.0 \mathrm{~Hz}, 1 \mathrm{H}), 5.18(\mathrm{dd}, \mathrm{J}=17.0,1.0 \mathrm{~Hz}, 1 \mathrm{H}), 4.10(\mathrm{dd}, \mathrm{J}=12.0$, $6.5 \mathrm{~Hz}, 1 \mathrm{H}), 3.90(\mathrm{dd}, \mathrm{J}=12.0 \mathrm{~Hz}, 6.5 \mathrm{~Hz}, 1 \mathrm{H}), 3.64(\mathrm{dd}, \mathrm{J}=8.0,3.0 \mathrm{~Hz}, 1 \mathrm{H})$, $3.56(q, J=6.5 \mathrm{~Hz}, 1 \mathrm{H}), 1.78$ (apparent hex, $\mathrm{J}=6.5 \mathrm{~Hz}, 1 \mathrm{H}), 1.62(\mathrm{~m}, 1 \mathrm{H}), 1.60$ $(\mathrm{s}, 3 \mathrm{H}), 1.55(\mathrm{OH})(\mathrm{bs}, 1 \mathrm{H}), 1.49$ (apparent sept, $\mathrm{J}=7.0,1 \mathrm{H}), 0.98(\mathrm{~d}, \mathrm{~J}=6.5,3 \mathrm{H})$, $0.90(\mathrm{t}, \mathrm{J}=7.5 \mathrm{~Hz}, 3 \mathrm{H}), 0.81(\mathrm{~d}, \mathrm{~J}=6.5 \mathrm{~Hz}, 3 \mathrm{H}) ;{ }^{13} \mathrm{C} \mathrm{NMR}\left(125.8 \mathrm{MHz}, \mathrm{CDCl}_{3}\right) \delta$ $140.3,139.3,124.5,117.2,83.6,82.4,64.5,31.0,28.5,19.6,18.5,11.9,10.0$ HRMS $m / z$ (ESI, $\mathrm{M}+\mathrm{Na}^{+}$) calcd 235.1669 found 235.1670.

The $S, S$ diastereomer was not directly synthesized; however, those peaks which were resolvable from the $S, R$ diastereomer were: ${ }^{1} \mathrm{H}$ NMR $\left(500 \mathrm{MHz}, \mathrm{CDCl}_{3}\right) \delta$ $4.06(\mathrm{dd}, \mathrm{J}=12.0,5.5 \mathrm{~Hz}, 1 \mathrm{H}), 3.94(\mathrm{dd}, \mathrm{J}=12.0,7.0 \mathrm{~Hz}, 1 \mathrm{H})$.

10B: IR 3454 (b, m), 2962 (s), 2934 (s), 2872 (s), 1669 (w), $1466(\mathrm{~m}), 1319$ (m), 1056 (s); the diastereomers were not separated, peaks belonging to a specific diastereomer are indicated by subscripts $A$ or $B$, those peaks labeled $A$ were favored with achiral phosphines and $(R)$-18. 'H NMR (500 $\left.\mathrm{MHz}, \mathrm{CDCl}_{3}\right) \delta 5.70$ $(\mathrm{m}, 1 \mathrm{H}), 5.64(\mathrm{~m}, 1 \mathrm{H}), 5.24(\mathrm{~m}, 2 \mathrm{H}), 4.30_{A}(\mathrm{~d}, \mathrm{~J}=11.0,1 \mathrm{H}), 4.09_{B}(\mathrm{~d}, \mathrm{~J}=11.0 \mathrm{~Hz}$ $1 \mathrm{H}), 4.04_{B}(\mathrm{~d}, \mathrm{~J}=11.0 \mathrm{~Hz}, 1 \mathrm{H}), 3.80_{A}(\mathrm{~d}, \mathrm{~J}=11.0 \mathrm{~Hz}, 1 \mathrm{H}), 3.58(\mathrm{~m}, 2 \mathrm{H}), 2.86$ $(\mathrm{OH})(\mathrm{d}, \mathrm{J}=7.0,1 \mathrm{H}), 1.80(\mathrm{~m}, 1 \mathrm{H}), 1.69($ apparent $\mathrm{t}, \mathrm{J}=7.0,3 \mathrm{H}), 1.63(\mathrm{M}, 1 \mathrm{H})$, 
$1.52(\mathrm{~m}, \mathrm{IH}), 1.03_{A}(\mathrm{~d}, \mathrm{~J}=6.0 \mathrm{~Hz}, 3 \mathrm{H}), 1.03_{B}(\mathrm{~d}, \mathrm{~J}=6.0 \mathrm{~Hz}, 3 \mathrm{H}), 0.91_{A}(\mathrm{t}, \mathrm{J}=7.5$

$\mathrm{Hz}, 3 \mathrm{H}), 0.89_{B}(\mathrm{t}, \mathrm{J}=7.5 \mathrm{~Hz}, 3 \mathrm{H}), 0.77_{A}(\mathrm{~d}, \mathrm{~J}=6.0 \mathrm{~Hz}, 3 \mathrm{H}), 0.75_{B}(\mathrm{~d}, \mathrm{~J}=6.0 \mathrm{~Hz}$, $3 \mathrm{H})$; no attempt was made to specify which carbon signals belonged to each diastereomer, there are exactly double the number of expected signals for a single compound. ${ }^{13} \mathrm{C}$ NMR $\left(125.8 \mathrm{MHz}, \mathrm{CDCl}_{3}\right) \delta 138.7,138.7,127.2,127.0,118.0$, $117.8,84.3,84.0,83.6,83.3,64.5,64.2,32.6,32.5,28.6,28.5,19.8,19.8,19.3$, 19.2, 13.4, 13.4, 10.1, 9.9; HRMS $m / z$ (ESI, $\mathrm{M}+\mathrm{Na}^{+}$) calcd 235.1669 found 235.1672 .

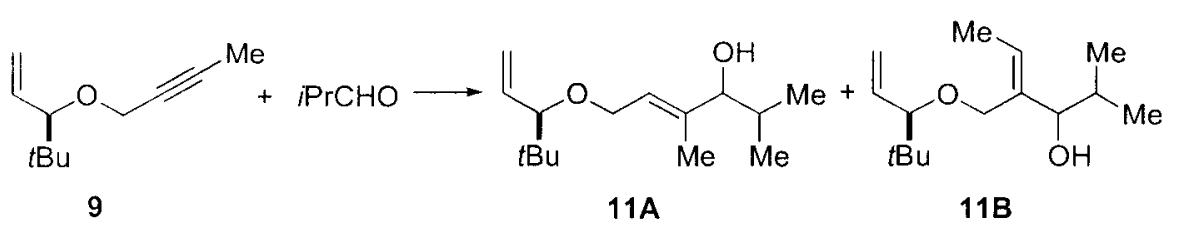

$9+i \mathrm{PrCHO}$ :

relative stereochemistry of $11 \mathrm{~A}$ based on analogy to $10 \mathrm{~A}$.

no phosphine: $9(83 \mathrm{mg}, 0.5 \mathrm{mmol})$ was reacted with $i \operatorname{PrCHO}(90 \mu \mathrm{L}, 1.0 \mathrm{mmol})$ in the presence of $\mathrm{Ni}(\operatorname{cod})_{2}(14 \mathrm{mg}, 0.05 \mathrm{mmol})$ and $\mathrm{Et}_{3} \mathrm{~B}(0.15 \mathrm{~mL}, 1.0 \mathrm{mmol})$. Crude material was chromatographed with 15:1 hexanes:diethyl ether $\rightarrow$ 8:1 hexanes: ethyl acetate to give $33 \mathrm{mg}(28 \%)$ of $\mathbf{1 1 A}$ as a clear oil $\mathrm{R}_{\mathrm{F}}=0.43(6: 1$ hexanes:EtOAc, $\mathrm{KMnO}_{4}$ ) (single regioisomer, >95:5 ( \pm ) $S, S: S, R$ ).

PCyp $_{3}: 9(83 \mathrm{mg}, 0.5 \mathrm{mmol})$ was reacted with $i \mathrm{PrCHO}(90 \mu \mathrm{L}, 1.0 \mathrm{mmol})$ in the presence of $\mathrm{Ni}(\mathrm{cod})_{2}(14 \mathrm{mg}, 0.05 \mathrm{mmol}), \mathrm{PCyp}_{3}(28 \mu \mathrm{L}, 0.1 \mathrm{mmol})$, and $\mathrm{Et}_{3} \mathrm{~B}$ $(0.15 \mathrm{~mL}, 1.0 \mathrm{mmol})$. Crude material was chromatographed with 15:1 hexanes:diethyl ether $\rightarrow$ 9:1 hexanes:ethyl acetate to give $22 \mathrm{mg}(18 \%)$ of $\mathbf{1 1 B}$ as a clear oil $\mathrm{R}_{\mathrm{F}}=0.55\left(6: 1\right.$ hexanes: $\mathrm{EtOAc}, \mathrm{KMnO}_{4}$ ) (single regioisomer, 42:58 mixture of diastereomers). 
$\mathrm{PBu}_{3}: 9(83 \mathrm{mg}, 0.5 \mathrm{mmol})$ was reacted with $i \mathrm{PrCHO}(90 \mu \mathrm{L}, 1.0 \mathrm{mmol})$ in the presence of $\mathrm{Ni}(\operatorname{cod})_{2}(14 \mathrm{mg}, 0.05 \mathrm{mmol}), \mathrm{PBu}_{3}(25 \mu \mathrm{L}, 0.1 \mathrm{mmol})$, and $\mathrm{Et}_{3} \mathrm{~B}(0.15$ $\mathrm{mL}, 1.0 \mathrm{mmol}$ ). Crude material was chromatographed with 15:1 hexanes:diethyl ether $\rightarrow$ 9:1 hexanes:ethyl acetate to give $15.6 \mathrm{mg}(13 \%)$ of $\mathbf{1 1 A}$ and $14.8 \mathrm{mg}$ (12\%) of 11B as clear oils (11A: 45:55 mixture of diastereomers; 11B: 42:58 mixture of diastereomers).

11A: IR 3411 (b, m), 2962 (s), 2956 (s), 2872 (s), 2870 (s), 2361 (w), 1465 (m), 1363 (s), $1016(\mathrm{~b}, \mathrm{~s}), 925$ (s); ${ }^{1} \mathrm{H}$ NMR $\left(500 \mathrm{MHz}, \mathrm{CDCl}_{3}\right)$-data is for $( \pm)-R, R$ diastereomer- $\delta 5.72($ ddd, $\mathrm{J}=17.5,10.0,8.5 \mathrm{~Hz}, 1 \mathrm{H}), 5.52(\mathrm{t}, \mathrm{J}=6.0 \mathrm{~Hz}, 1 \mathrm{H})$, $5.25(\mathrm{dd}, \mathrm{J}=10.0,1.5 \mathrm{~Hz}, 1 \mathrm{H}), 5.14(\mathrm{dd}, \mathrm{J}=17.5,1.5 \mathrm{~Hz}, 1 \mathrm{H}), 4.08(\mathrm{dd}, \mathrm{J}=12.5$, $6.0 \mathrm{~Hz}, 1 \mathrm{H}), 3.86(\mathrm{dd}, \mathrm{J}=12.5 \mathrm{~Hz}, 7.0 \mathrm{~Hz}, 1 \mathrm{H}), 3.64(\mathrm{dd}, \mathrm{J}=8.5,3.0 \mathrm{~Hz}, 1 \mathrm{H})$, $3.21(\mathrm{~d}, \mathrm{~J}=8.5 \mathrm{~Hz}, 1 \mathrm{H}), 1.78$ (apparent hex, $\mathrm{J}=7.0 \mathrm{~Hz}, 1 \mathrm{H}), 1.60(\mathrm{~s}, 3 \mathrm{H}), 1.54$ $(\mathrm{OH})(\mathrm{d}, \mathrm{J}=3.0 \mathrm{~Hz}, 1 \mathrm{H}), 0.99(\mathrm{~d}, \mathrm{~J}=7.0,3 \mathrm{H}), 0.88(\mathrm{~s}, 9 \mathrm{H}), 0.82(\mathrm{~d}, \mathrm{~J}=7.0 \mathrm{~Hz}$, $3 \mathrm{H}),{ }^{13} \mathrm{C} \mathrm{NMR}\left(125.8 \mathrm{MHz}, \mathrm{CDCl}_{3}\right) \delta 140.3,139.3,124.5,117.2,83.6,82.4,64.5$, 31.0, 28.5, 19.6, 18.5, 11.9, 10.0; HRMS $m / z\left(\mathrm{ESI}, \mathrm{M}+\mathrm{Na}^{+}\right)$calcd 263.1982 found 263.1982 .

The $( \pm)-R, S$ diastereomer was not directly synthesized; however, those peaks which were resolvable from the $( \pm)-R, R$ diastereomer were: ${ }^{1} \mathrm{H}$ NMR $(500 \mathrm{MHz}$, $\left.\mathrm{CDCl}_{3}\right) \delta 4.05(\mathrm{dd}, \mathrm{J}=12.5,5.5 \mathrm{~Hz}, 1 \mathrm{H}), 3.23(\mathrm{~d}, \mathrm{~J}=8.5 \mathrm{~Hz}, 1 \mathrm{H}), 0.97(\mathrm{~d}, \mathrm{~J}=6.5$ $\mathrm{Hz}, 3 \mathrm{H}), 0.89(\mathrm{~s}, 9 \mathrm{H})$.

11B: IR 3462 (b, m), 2956 (s), $2870(\mathrm{~s}), 2361(\mathrm{w}), 1670(\mathrm{~b}, \mathrm{w}), 1465(\mathrm{~m}), 1364(\mathrm{~m})$ 1068 (s); the diastereomers were not separated, peaks belonging to a specific diastereomer are indicated by subscripts $A$ or $B$, with achiral phosphines $A$ was the major product. 'H NMR (500 $\left.\mathrm{MHz}, \mathrm{CDCl}_{3}\right) \delta 5.72(\mathrm{~m}, 1 \mathrm{H}), 5.61$ (apparent $\mathrm{q}, \mathrm{J}=$ 
$6.5,1 \mathrm{H}), 5.32_{A}(\mathrm{dd}, \mathrm{J}=10.5,2.0 \mathrm{~Hz}, 1 \mathrm{H}), 5.31_{B}(\mathrm{dd}, \mathrm{J}=10.5,2.0 \mathrm{~Hz}, 1 \mathrm{H}), 5.21(\mathrm{~d}$, $\mathrm{J}=17.5 \mathrm{~Hz}, 1 \mathrm{H}), 4.29_{B}(\mathrm{~d}, \mathrm{~J}=11.0,1 \mathrm{H}), 4.08_{A}(\mathrm{~d}, \mathrm{~J}=11.0 \mathrm{~Hz}, 1 \mathrm{H}), 3.94_{A}(\mathrm{~d}, \mathrm{~J}=$ $11.0 \mathrm{~Hz}, 1 \mathrm{H}), 3.74_{B}(\mathrm{~d}, \mathrm{~J}=11.0 \mathrm{~Hz}, \mathrm{IH}), 3.56(\mathrm{q}, \mathrm{J}=7.0,1 \mathrm{H}), 3.27_{B}(\mathrm{~d}, \mathrm{~J}=8.0$ $\mathrm{Hz}, 1 \mathrm{H}), 3.23_{A}(\mathrm{~d}, \mathrm{~J}=8.0 \mathrm{~Hz}, 1 \mathrm{H}), 2.85_{B}(\mathrm{OH})(\mathrm{d}, \mathrm{J}=7.0 \mathrm{~Hz}, 1 \mathrm{H}), 2.82_{A}(\mathrm{OH})(\mathrm{d}$, $\mathrm{J}=7.0 \mathrm{~Hz}, 1 \mathrm{H}), 1.80(\mathrm{~m}, 1 \mathrm{H}), 1.66(\mathrm{~m}, 3 \mathrm{H}), 1.63(\mathrm{M}, 1 \mathrm{H}), 1.03$ (apparent $\mathrm{t}, \mathrm{J}=$ $6.5 \mathrm{~Hz}, 3 \mathrm{H}), \quad 0.90_{B}(\mathrm{~s}, 9 \mathrm{H}), 0.89_{A}(\mathrm{~s}, 9 \mathrm{H}), 0.76$ (apparent $\left.\mathrm{t}, \mathrm{J}=6.0 \mathrm{~Hz}, 3 \mathrm{H}\right)$; no attempt was made to specify which carbon signals belonged to each diastereomer, there are exactly double the number of expected signals for a single compound. ${ }^{13} \mathrm{C} \mathrm{NMR}\left(125.8 \mathrm{MHz}, \mathrm{CDCl}_{3}\right) \delta 137.3,137.1,135.9,135.8,126.8,126.7,119.5$, $119.3,90.6,90.6,84.4,84.3,65.0,64.8,34.6,34.6,32.5,32.4,26.4,26.3,19.9$, $19.8,19.3,19.3,13.4,13.4 ;$ HRMS $m / z\left(E S I, M+\mathrm{Na}^{+}\right.$) calcd 263.1982 found 263.1986<smiles>CC(=O)OC(C(C)=O)C(C)C</smiles>

(+)-12: To a cold $\left(0^{\circ} \mathrm{C}\right)$ solution of $(-)-\mathbf{1 0 A}(35 \mathrm{mg}, 0.165 \mathrm{mmol})$ in DCM (1.5 ml) was added $\mathrm{NEt}_{3}(71 \mu \mathrm{L}, 0.51 \mathrm{mmol}), \mathrm{Ac}_{2} \mathrm{O}(24 \mu \mathrm{L}, 0.25 \mathrm{mmol})$, and DMAP (2 $\mathrm{mg}, 0.016 \mathrm{mmol}$ ). The mixture was warmed to room temperature and stirred for 1.5 hours. At this point it was concentrated in vacuo and filtered through silica eluting with 10:1 hexanes:ethyl acetate. This afforded the crude acetate-protected product which was carried on to the ozonolysis without purification. The intermediate was dissolved in DCM ( $3 \mathrm{ml}$ ) cooled to $-78{ }^{\circ} \mathrm{C}$ and exposed to $\mathrm{O}_{3}$ until the reaction was dark blue. The solution was then degassed with argon and $\mathrm{PPh}_{3}(600 \mathrm{mg})$ was added. The reaction was allowed to warm to $0^{\circ} \mathrm{C}$ over 4 hours, and then concentrated in vacuo. The crude material was loaded onto a column (15:1 pentanes:DCM) with a minimal amount of DCM and then 
eluted with 15:1 pentanes:DCM until separation of $\mathrm{PPh}_{3}$ and byproducts was complete, then column was flushed with 1:1 pentanes:diethyl ether to give $(+)-12$ as a clear oil $(15.1$ mg, $58 \%$ over two steps $) .[\alpha]_{\mathrm{D}}+6.7$ (c 1.01, DCM, $\left.22{ }^{\circ} \mathrm{C}\right) ;{ }^{1} \mathrm{H}$ NMR $\left(500 \mathrm{MHz}, \mathrm{CDCl}_{3}\right)$ $\delta 4.87(\mathrm{~d}, \mathrm{~J}=4.0 \mathrm{~Hz}, 1 \mathrm{H}), 2.24(\mathrm{~m}, 1 \mathrm{H}), 2.17(\mathrm{~s}, 3 \mathrm{H}), 2.16(\mathrm{~s}, 3 \mathrm{H}), 1.01(\mathrm{~d}, \mathrm{~J}=7.0 \mathrm{~Hz}$ $3 \mathrm{H}), 0.93(\mathrm{~d}, \mathrm{~J}=7.0 \mathrm{~Hz}, 3 \mathrm{H}) ;{ }^{13} \mathrm{C} \mathrm{NMR}\left(125.8 \mathrm{MHz} \mathrm{CDCl}_{3}\right) \delta 205.6,171.0,83.0,29.6$, $27.2,20.8,19.4,17.0$.

$(+)-12$ : Following the listed procedure $\mathbf{1 7}(42 \mathrm{mg}, 0.2 \mathrm{mmol})$ was converted to $(+)-\mathbf{1 2}$ (20.5 mg, $66 \%)$ over two steps. $[\alpha]_{\mathrm{D}}+7.7\left(c 1.4, \mathrm{DCM}, 22^{\circ} \mathrm{C}\right)$.

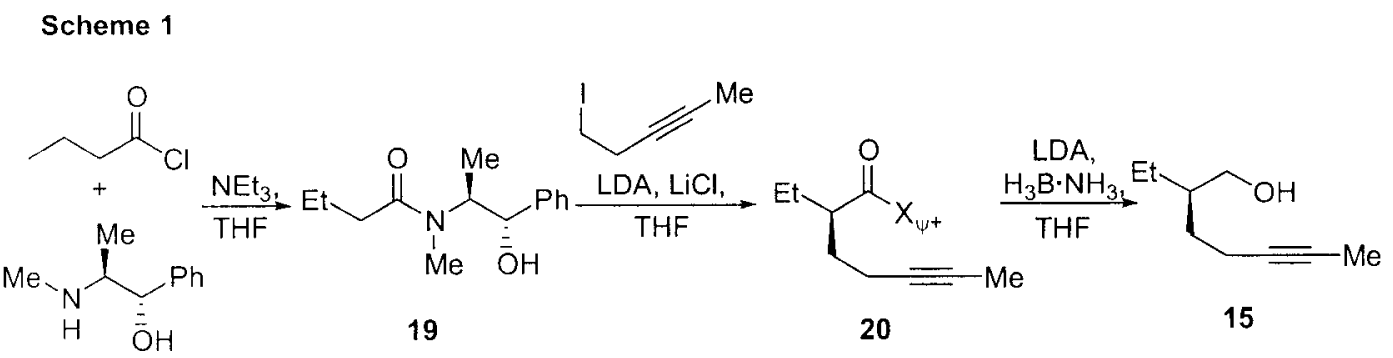

15: The synthesis of $\mathbf{1 5}$ was accomplished following the work of Myers and co-workers (Scheme 1). ${ }^{5}$ Butyryl chloride $(3.1 \mathrm{ml}, 30 \mathrm{mmol})$ was added dropwise to a chilled $\left(0^{\circ} \mathrm{C}\right)$ solution of $(+)-(S, S)$-pseudoephedrine $(4.95 \mathrm{~g}, 30 \mathrm{mmol})$ and $\mathrm{NEt}_{3}(5.4 \mathrm{ml}, 39 \mathrm{mmol})$ in THF $(10 \mathrm{ml})$. The reaction was stirred for 30 minutes and then quenched by the addition of water. The product mixture was partitioned between ethyl acetate and brine, the organic layer was separated, washed 2 times with brine, and then dried over sodium sulfate. The solvent was removed in vacuo and the crude solid recrystallized from toluene (20 mL) to give 19 as white crystals $(5.15 \mathrm{~g}, 74 \%)$. NMR matched known values. ${ }^{6}$ $n$ Butyl lithium $(2.5 \mathrm{M}$ in hexanes, $9.8 \mathrm{ml}, 24.5 \mathrm{mmol})$ was added dropwise to a cold $(-78$ ${ }^{\circ} \mathrm{C}$ ) slurry of $i \mathrm{Pr}_{2} \mathrm{NH}(3.7 \mathrm{~mL}, 26 \mathrm{mmol})$ and $\mathrm{LiCl}$ (flame dried under vacuum prior to use) ( $3.23 \mathrm{~g}, 77 \mathrm{mmol})$ in THF $(17 \mathrm{~mL})$. The suspension was warmed to $0{ }^{\circ} \mathrm{C}$ for 5 minutes 
then cooled to $-78^{\circ} \mathrm{C} .19(2.96 \mathrm{~g}, 12.6 \mathrm{mmol})$ was added dropwise as a solution in cold $\left(0{ }^{\circ} \mathrm{C}\right) \mathrm{THF}(37 \mathrm{~mL})$ and the reaction stirred at $-78{ }^{\circ} \mathrm{C}$ for 1 hour, $0{ }^{\circ} \mathrm{C}$ for 15 minutes and then room temperature for 5 minutes before being re-cooled to $0{ }^{\circ} \mathrm{C}$. 5-iodo-2-pentyne ( $1.16 \mathrm{~g}, 6.0 \mathrm{mmol}$ ), available in two steps from the corresponding alcohol, ${ }^{7}$ was added in a single portion and the reaction was stirred at $0{ }^{\circ} \mathrm{C}$ for 2 hours before being allowed to gradually warm to room temperature overnight. The reaction was quenched via the addition of saturated aqueous ammonium chloride and the product extracted with ethyl acetate. The combined organics were dried over sodium sulfate, filtered, concentrated and then chromatographed (3:2 hexanes:ethyl acetate) to give $\mathbf{2 0}$ as a viscous pale yellow oil $(1.34 \mathrm{~g}, 73 \%)$. The relative stereochemistry of $\mathbf{2 0}$ was assigned by analogy to Myers' work.. ${ }^{5}$

20 was reduced using $\mathrm{LDA}$ and $\mathrm{H}_{3} \mathrm{~B} \cdot \mathrm{NH}_{3}$ (LAB) prepared as follows: $n$ Butyl lithium (2.5 $\mathrm{M}$ in hexanes, $5.3 \mathrm{~mL}, 13.2 \mathrm{mmol})$ was added dropwise to a cold $\left(-78^{\circ} \mathrm{C}\right)$ solution of $i \operatorname{Pr}_{2} \mathrm{NH}(2.0 \mathrm{~mL}, 13.9 \mathrm{mmol})$ in THF $(14 \mathrm{~mL})$. The solution was warmed to $0{ }^{\circ} \mathrm{C}$ and stirred for 10 minutes, then $\mathrm{H}_{3} \mathrm{~B} \cdot \mathrm{NH}_{3}(407 \mathrm{mg}, 13.2 \mathrm{mmol})$ was added in a single portion. The reaction was stirred at $0{ }^{\circ} \mathrm{C}$ for an additional 15 minutes and then warmed to room temperature for 15 minutes. The reaction was re-cooled $\left(0^{\circ} \mathrm{C}\right)$ for the dropwise addition of $20(1.0 \mathrm{~g}, 3.3 \mathrm{mmol})$ in THF $(8.3 \mathrm{~mL})$, and then warmed back up to room temperature until the reaction was determined to be complete by TLC ( 2 hours). The system was cooled to $0{ }^{\circ} \mathrm{C}$ and $33 \mathrm{~mL}$ of $3 \mathrm{~N} \mathrm{HCl}$ was added carefully. The slurry was stirred for 30 minutes at $0{ }^{\circ} \mathrm{C}$, the product was extracted with ether, and the combined organics washed with $1 \mathrm{~N} \mathrm{HCl}, 1 \mathrm{~N} \mathrm{NaOH}$, and brine. The crude product was dried over magnesium sulfate, filtered, concentrated and chromatographed (5:2 hexanes:diethyl ether) to give $\mathbf{1 5}$ as a clear oil $(267 \mathrm{mg}, 81 \%)$. The enantiomeric excess was approximated by formation of 
the Mosher ester of this sample and of racemic material ${ }^{8}$ and then comparing their respective ${ }^{1} \mathrm{H}$ NMR spectra. $[\alpha]_{\mathrm{D}}-4.6,\left(\mathrm{c} 3.37, \mathrm{CHCl}_{3}, 22{ }^{\circ} \mathrm{C}\right)$; IR 3348 (b, m), 2961 (s), $2921(\mathrm{~s}), 2876(\mathrm{~s}), 2361(\mathrm{~m}), 2341(\mathrm{~m}), 1461(\mathrm{~m}), 1380(\mathrm{w}), 1043(\mathrm{~m}) ;{ }^{1} \mathrm{H}$ NMR (500 $\left.\mathrm{MHz}_{z} \mathrm{CDCl}_{3}\right) d 3.60(\mathrm{~m}, 2 \mathrm{H}), 2.19(\mathrm{~m}, 2 \mathrm{H}), 1.79(\mathrm{t}, \mathrm{J}=2.5 \mathrm{~Hz}, 3 \mathrm{H}), 1.55(\mathrm{~m}, 2 \mathrm{H}), 1.39$ $(\mathrm{m}, 3 \mathrm{H}), 0.92(\mathrm{t}, \mathrm{J}=7.5 \mathrm{~Hz}, 3 \mathrm{H}) ;{ }^{13} \mathrm{C} \mathrm{NMR}\left(125.8 \mathrm{MHz}, \mathrm{CDCl}_{3}\right) \delta 79.5,75.9,64.9,41.3$, $30.1,23.4,16.6,11.3,3.7$.

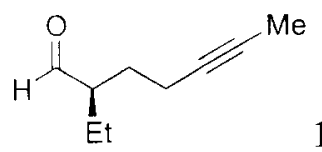

16: DMSO (298 $\mu \mathrm{L}, 4.2 \mathrm{mmol})$ was added to oxayl chloride $(262 \mu \mathrm{L}$, $3 \mathrm{mmol})$ in cold $\left(-78^{\circ} \mathrm{C}\right)$ dichloromethane $(20 \mathrm{~mL})$, and the mixture was stirred for 10 minutes before 15 ( $280 \mathrm{mg}, 2 \mathrm{mmol}$ ) was added. After stirring for an additional 20 minutes, $\mathrm{NEt}_{3}(836 \mu \mathrm{L}, 6 \mathrm{mmol})$ was added in a single portion, and the cold bath subsequently removed. The reaction was allowed to warm for 30 minutes before being quenched via the addition of water. The product was extracted with ether and the combined organics dried over magnesium sulfate. The solvent was removed under reduced pressure ( 80 torr, $0{ }^{\circ} \mathrm{C}$, rotary evaporator), and the crude mixture was flushed through a silica plug eluting with 10:1 pentanes:diethyl ether and then concentrated to give a clear oil (274 mg, 99\%). IR $2964(\mathrm{~m}), 2923(\mathrm{~m}), 2361$ (s), 2341 (s), $1726(\mathrm{~m})$, $1380(\mathrm{~b}, \mathrm{~m}), 1261(\mathrm{w}) ;$ 'H NMR $\left(500 \mathrm{MHz}, \mathrm{CDCl}_{3}\right) \delta 9.64(\mathrm{~d}, \mathrm{~J}=2.5 \mathrm{~Hz}, 1 \mathrm{H}), 2.39(\mathrm{dtt}$, $\left.J_{d}=2.5, J_{t}=7.5,5.5 \mathrm{~Hz}, 1 \mathrm{H}\right), 2.18(\mathrm{~m}, 2 \mathrm{H}), 1.87(\mathrm{~m}, 1 \mathrm{H}), 1.77(\mathrm{t}, \mathrm{J}=2.5 \mathrm{~Hz}, 3 \mathrm{H}), 1.70$ $(\mathrm{m}, 1 \mathrm{H}), 1.66-1.52(\mathrm{~m}, 4 \mathrm{H}), 0.94(\mathrm{t}, \mathrm{J}=7.5 \mathrm{~Hz}, 3 \mathrm{H}) ;{ }^{13} \mathrm{C} \mathrm{NMR}\left(125.8 \mathrm{MHz}, \mathrm{CDCl}_{3}\right) \delta$ $205.2,78.3,76.9,52.4,27.7,21.7,16.8,11.5,3.6 ; \mathrm{HRMS} m / z\left(E S I, \mathrm{M}+\mathrm{Na}^{+}\right)$calcd 161.0937 found 161.0944 . 


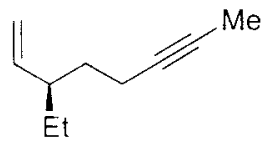

13: Freshly dried methyltriphenylphosphonium bromide (1.02 g, 2.86 mmol) was added in one portion to a cooled $\left(0^{\circ} \mathrm{C}\right)$ suspension of $\mathrm{KO} t \mathrm{Bu}(355 \mathrm{mg}, 2.86$ mmol) in ether ( $4 \mathrm{~mL})$, resulting in the suspension turning bright yellow. The suspension was warmed to room temperature and stirred for 40 minutes, 16 (274 $\mathrm{mg}, 2 \mathrm{mmol}$ ) was added from a $10 \mathrm{~mL}$ pear shaped flask, rinsing with ether (total volume $2 \mathrm{~mL}$ ). Stirring was continued for 45 minutes at room temperature and then the reaction was quenched with water $(200 \mu \mathrm{L})$. The suspension was stirred until all of the precipitate collected at the bottom of the flask $(5 \mathrm{~min}$ ) leaving a clear liquid phase. The flask was equipped with a short-path distillation apparatus and heated to $50{ }^{\circ} \mathrm{C}$ to remove most of the diethyl ether. The receiving flask was then cooled to $-78^{\circ} \mathrm{C}$ and the system was placed under vacuum resulting in the instantaneous transfer of all remaining liquid materials (a mixture of diethyl ether, $t \mathrm{BuOH}$, water, and 13) to the cooled receiving flask. Sodium sulfate was added to the biphasic mixture and then the material was passed through a plug of silica eluting with pentanes. The solvent was removed $\left(0{ }^{\circ} \mathrm{C}, 140\right.$ torr $)$ to give 13 as a clear oil (175 mg, 64\%). [ $\alpha]_{\mathrm{D}}-21.1\left(\mathrm{c} 0.41, \mathrm{DCM}, 22^{\circ} \mathrm{C}\right) ; \mathrm{IR} 3077(\mathrm{w}), 2964(\mathrm{~s}), 2921(\mathrm{~s}), 2875$ (m), $2361(\mathrm{w}), 1640(\mathrm{w}), 1455(\mathrm{~m}), 997(\mathrm{~m}), 914(\mathrm{~s}) ;{ }^{1} \mathrm{H}$ NMR (500 MHz, $\left.\mathrm{CDCl}_{3}\right) \delta 5.48$ $(\mathrm{ddd}, \mathrm{J}=17.0,10.0,9.5 \mathrm{~Hz}, 1 \mathrm{H}), 5.00(\mathrm{~m}, 2 \mathrm{H}), 2.16(\mathrm{~m}, 1 \mathrm{H}), 2.06(\mathrm{~m}, 1 \mathrm{H}), 1.98(\mathrm{~m}, 1 \mathrm{H})$, $1.79(\mathrm{t}, \mathrm{J}=2.5 \mathrm{~Hz}, 3 \mathrm{H}), 1.60(\mathrm{~m}, 1 \mathrm{H}), 1.40(\mathrm{~m}, 2 \mathrm{H}), 1.26(\mathrm{~m}, 1 \mathrm{H}), 0.86(\mathrm{t}, \mathrm{J}=7.5 \mathrm{~Hz}$, $3 \mathrm{H}) ;{ }^{13} \mathrm{C} \mathrm{NMR}\left(125.8 \mathrm{MHz}, \mathrm{CDCl}_{3}\right) \delta 142.3,115.3,79.5,75.5,45.2,34.1,27.7,16.8$, 11.8, 3.7; HRMS $m / z\left(E I, M^{+}\right)$calcd 136.1248 found 136.1247 .

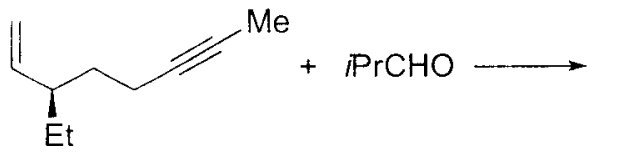

13

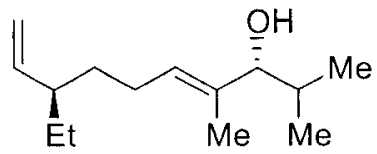

17 
17: Following the general procedure for nickel-catalyzed reductive coupling (conditions I) yielded $82 \mathrm{mg}(78 \%)$ of $\mathbf{1 7}$ as a single regioisomer and as a mixture of diastereomers (91:1 $R, R$, to $R, S) . \mathrm{R}_{\mathrm{f}}=0.48$ (6:1 hexanes:EtOAc, $\left.\mathrm{KMnO}_{4}\right)[\alpha]_{\mathrm{D}}-0.45(c 0.84, \mathrm{DCM}$, $22{ }^{\circ} \mathrm{C}$ ); IR 3391 (b, m), 2959 (s), 2922 (s), 2872 (s), 1640 (w), 1460 (m), 1121 (w), 1010 (s), $911(\mathrm{~s}) ;{ }^{1} \mathrm{H}$ NMR $\left(500 \mathrm{MHz}, \mathrm{CDCl}_{3}\right)$-data is for $R, R$ diastereomer- $\delta 5.52$ (ddd, $\mathrm{J}=$ 17.0, 10.0, 9.0 Hz, 1H), $5.34(\mathrm{t}, \mathrm{J}=7.0 \mathrm{~Hz}, 1 \mathrm{H}), 5.00(\mathrm{dd}, \mathrm{J}=10.0,2.0 \mathrm{~Hz}, 1 \mathrm{H}), 4.95(\mathrm{dd}$, $J=17.0,2.0 \mathrm{~Hz}, 1 \mathrm{H}), 3.57(\mathrm{dd}, \mathrm{J}=9.0,3.0 \mathrm{~Hz}, 1 \mathrm{H}), 2.01(\mathrm{~m}, 2 \mathrm{H}), 1.86(\mathrm{~m}, 1 \mathrm{H}), 1.76(\mathrm{~m}$, IH), $1.58(\mathrm{~s}, 3 \mathrm{H}), 1.43(\mathrm{~m}, 2 \mathrm{H}), 1.39(\mathrm{OH})(\mathrm{d}, \mathrm{J}=3.0 \mathrm{~Hz}, 1 \mathrm{H}), 1.28(\mathrm{~m}, 2 \mathrm{H}), 0.99(\mathrm{~d}, \mathrm{~J}=$ $7.0 \mathrm{~Hz}, 3 \mathrm{H}), 0.85(\mathrm{t}, \mathrm{J}=7.0 \mathrm{~Hz}, 3 \mathrm{H}), 0.78(\mathrm{~d}, \mathrm{~J}=7.0 \mathrm{~Hz}, 3 \mathrm{H}) ;{ }^{13} \mathrm{C}$ NMR $(125.8 \mathrm{MHz}$, $\left.\mathrm{CDCl}_{3}\right) \delta 143.1,136.5,128.2,114.8,84.5,45.7,34.6,31.3,28.0,25.4,19.7,18.9,11.9$, 11.4 .

The $R, S$ diastereomer was not directly synthesized; however, those peaks which were resolvable from the $R, R$ diastereomer were: ${ }^{1} \mathrm{H}$ NMR $\left(500 \mathrm{MHz}, \mathrm{CDCl}_{3}\right) \delta 5.56(\mathrm{ddd}, \mathrm{J}=$ $17.0,10.0,9.0 \mathrm{~Hz}, 1 \mathrm{H}), 4.10(\mathrm{dd}, \mathrm{J}=9.0,3.0 \mathrm{~Hz}, 1 \mathrm{H}), 1.07(\mathrm{~d}, \mathrm{~J}=6.0,3 \mathrm{H}), 0.72(\mathrm{~d}, \mathrm{~J}=$ $6.0 \mathrm{~Hz}, 3 \mathrm{H})$.

\section{References:}

\footnotetext{
Midland, M. M.; Koops, R. W. J. Org. Chem. 1990, 55, 5058-5065.

'Hill, M. L.; Raphael, R. A. Tetrahedron, 1990, 46, 4487-4594.

${ }^{3}$ Kagan, H. B. Stereochemistry, George Thieme Stuggart, 1977, vol. 4, pg 224.

'Miller, K. M.; Colby, E. A.; Woodin, K. S.; Jamison, T. F. Adv. Synth. Catal. 2005, 347, 1533-1536.

${ }^{5}$ Myers, A. G.; Yang, B. H.; Chen, H.; McKinstry, L.; Kopecky, D. J.; Gleason, J. L. J. Am. Chem. Soc. 1997, 119,6496-6511.

"Meyers, M. J.; Sun, J.; Carlson, K. E.; Katzenellenbogen, B. S.; Katzenellenbogen, J. A. J. Med. Chem. 1999, 42, 2456-2468.

${ }^{7}$ Ansell, M. F.; Emmett, J. C.; Coombs, R. V. J. Chem. Soc. C., 1968, 217-224.

${ }^{8}$ Racemic material was available using the chemistry of Hodgson and co-workers. Hodgson, D. M.; Bray, C. D.; Kindon, N. D. J. Am. Chem. Soc. 2004, 126, 6870-6871.
} 


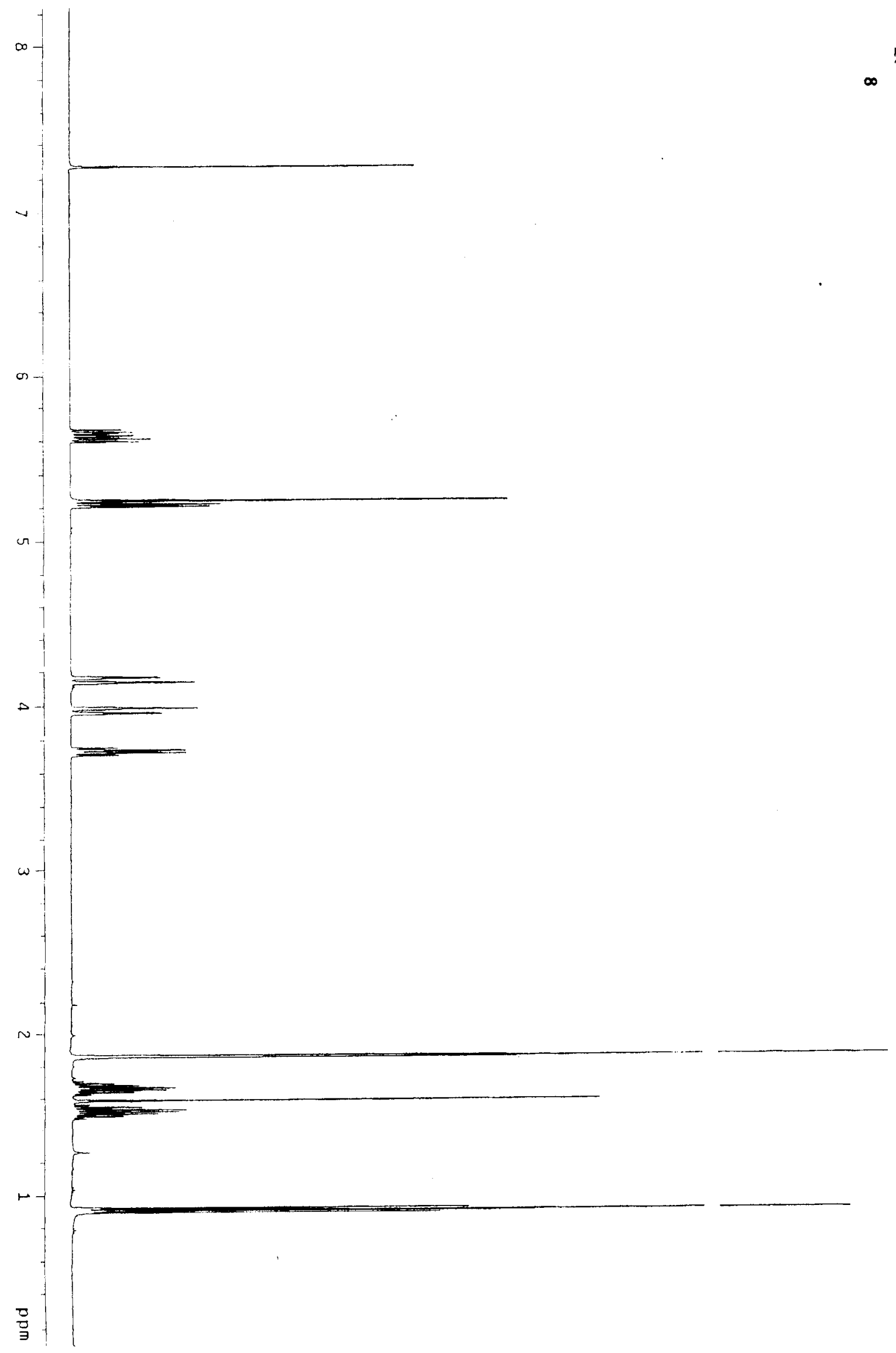




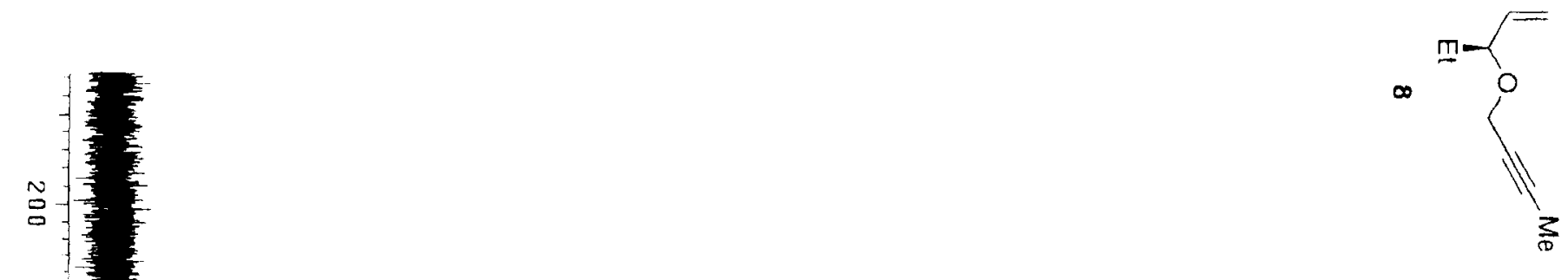




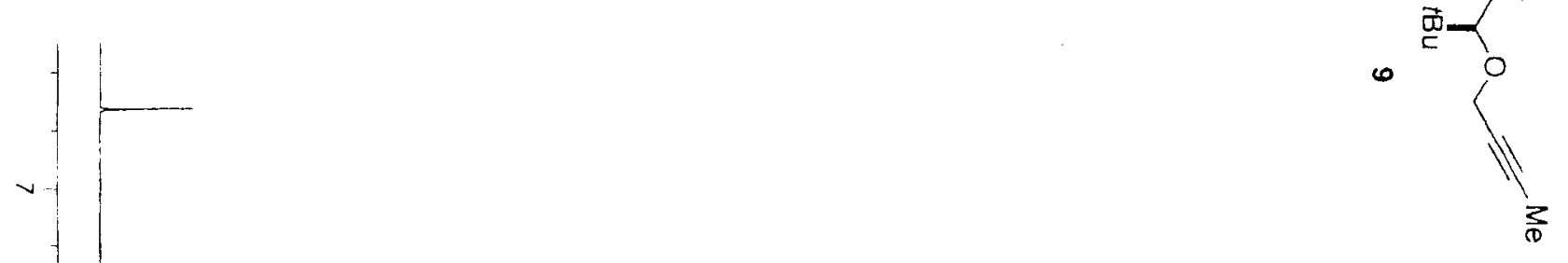

a

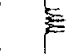

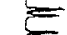

4

$+1$

$+$

$\omega-$

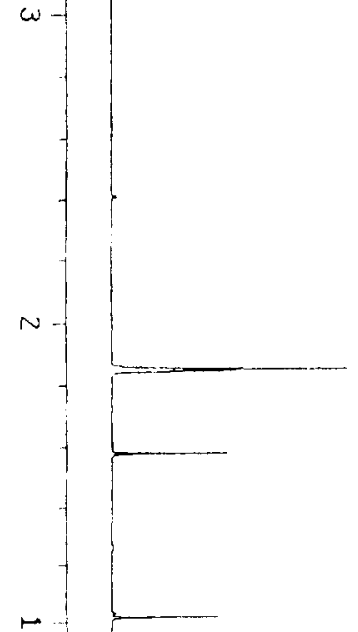

믑 


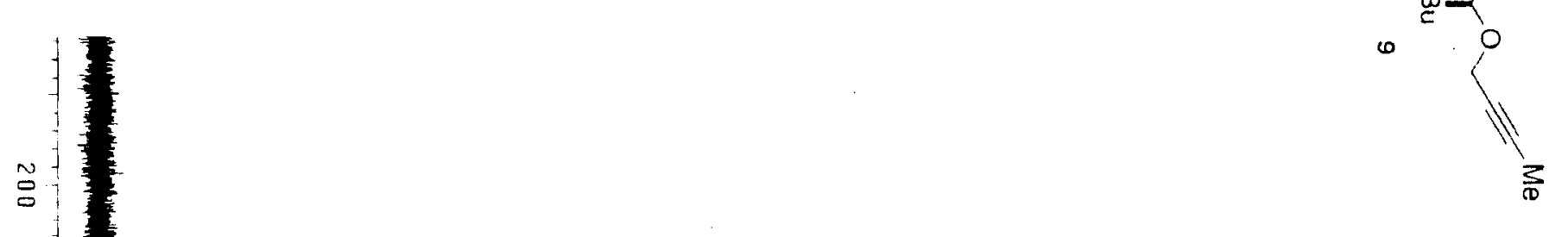

品.

-

$\stackrel{\infty}{\infty}=$

$\vec{\circ}$

멈

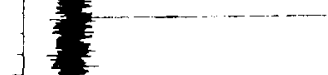

$-1$

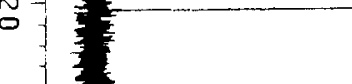

0

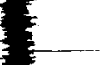

0

:

$\circ$

$-$

‥

品者 


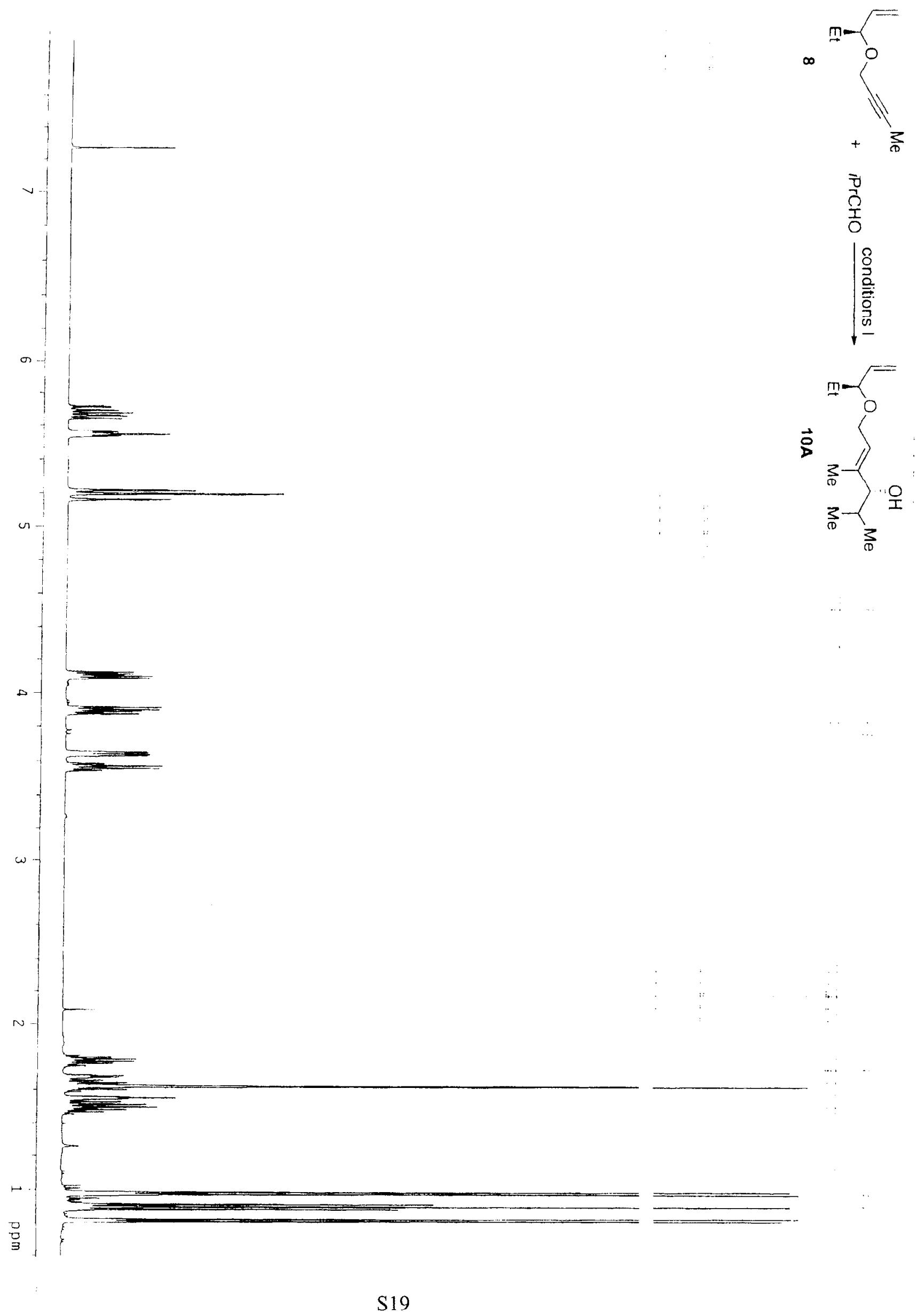



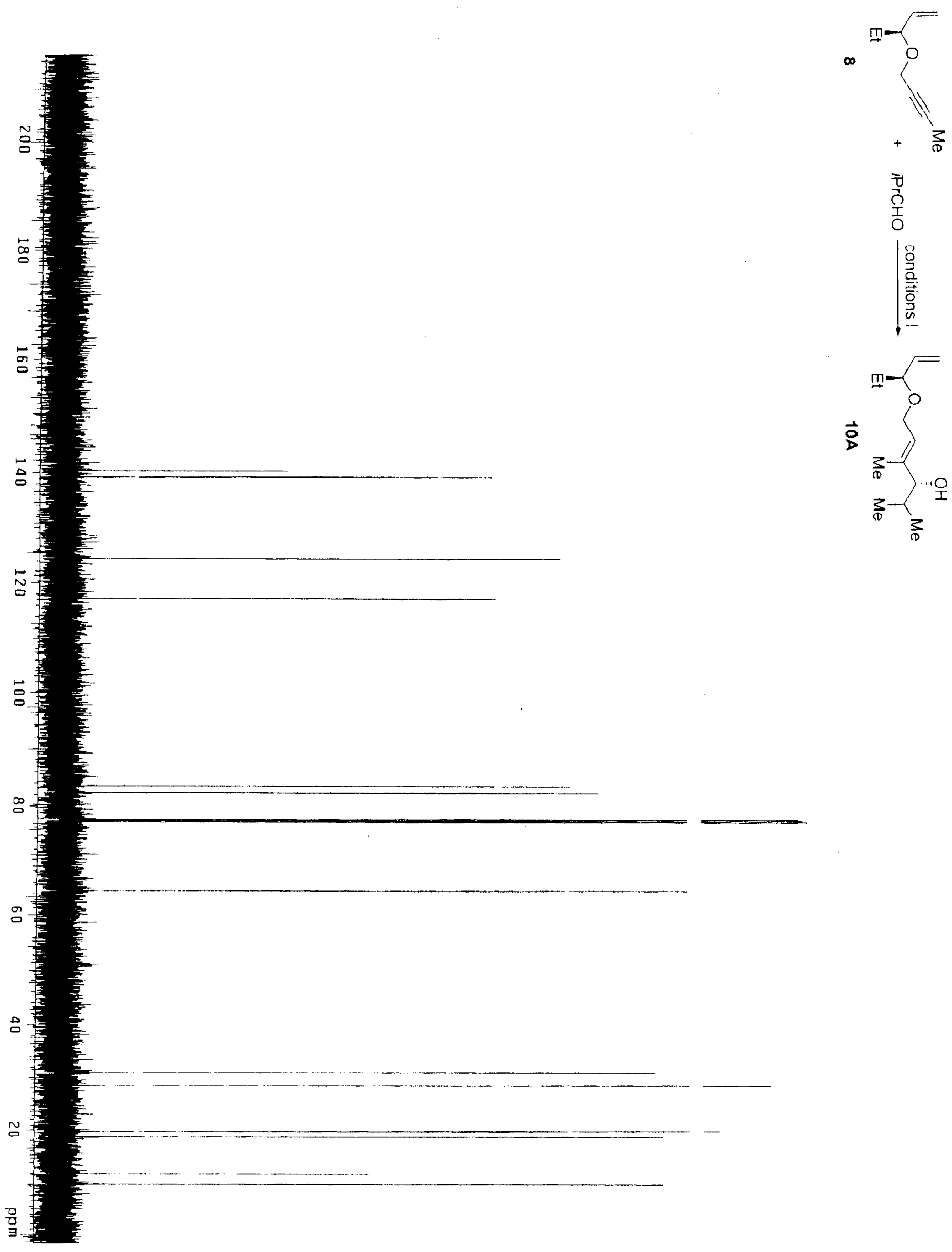


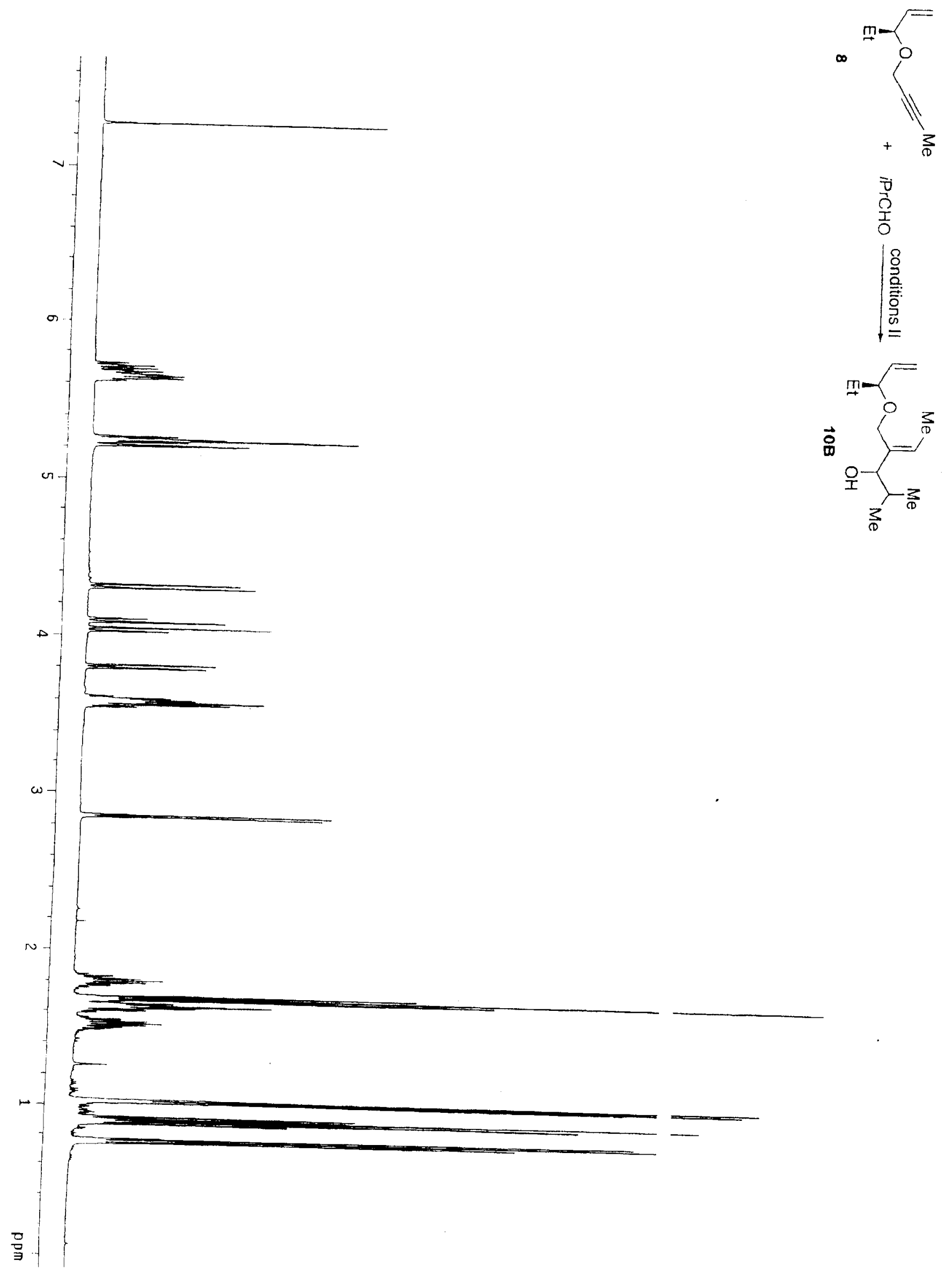




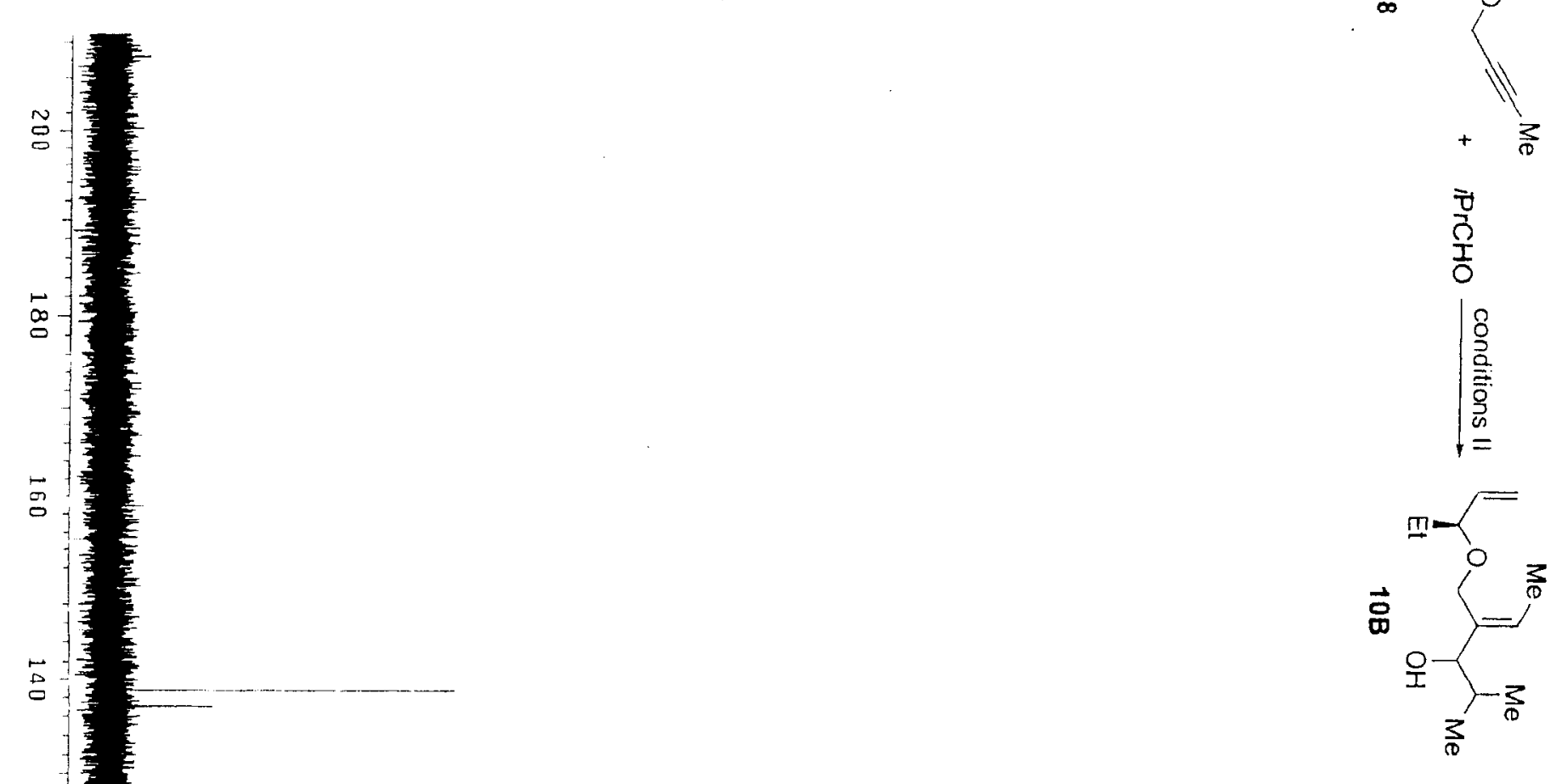

品

$\infty$

ㅁ.

$B$

$B$

0

.
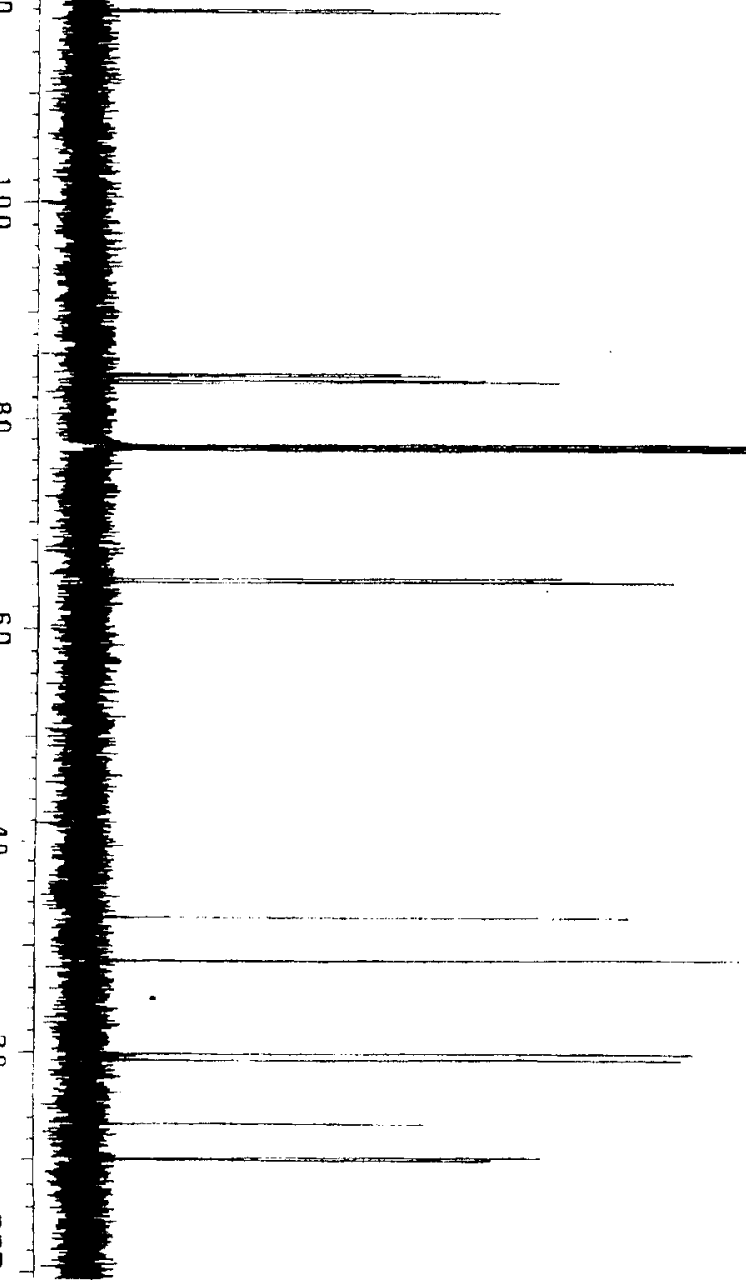


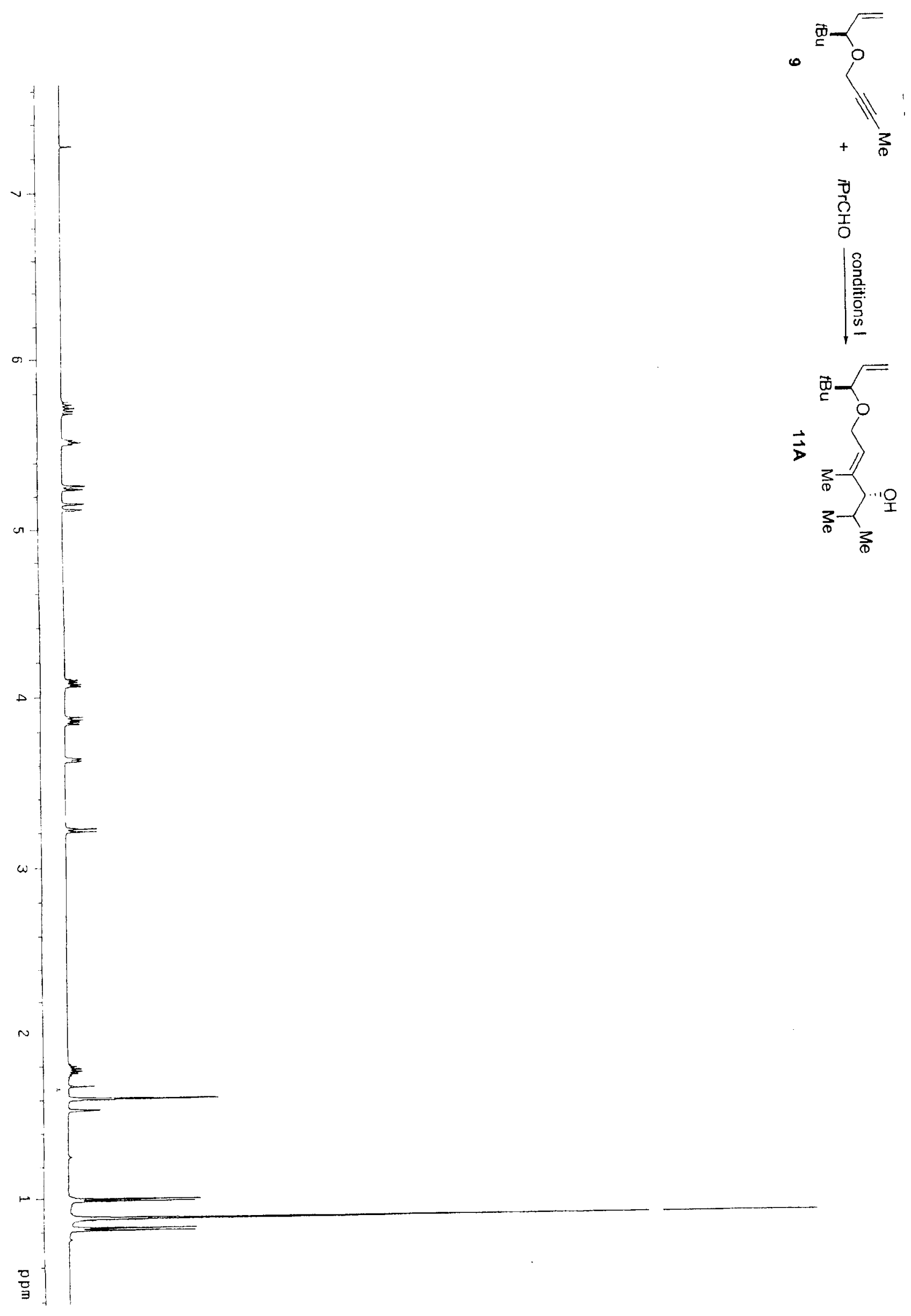




$$
\mid
$$




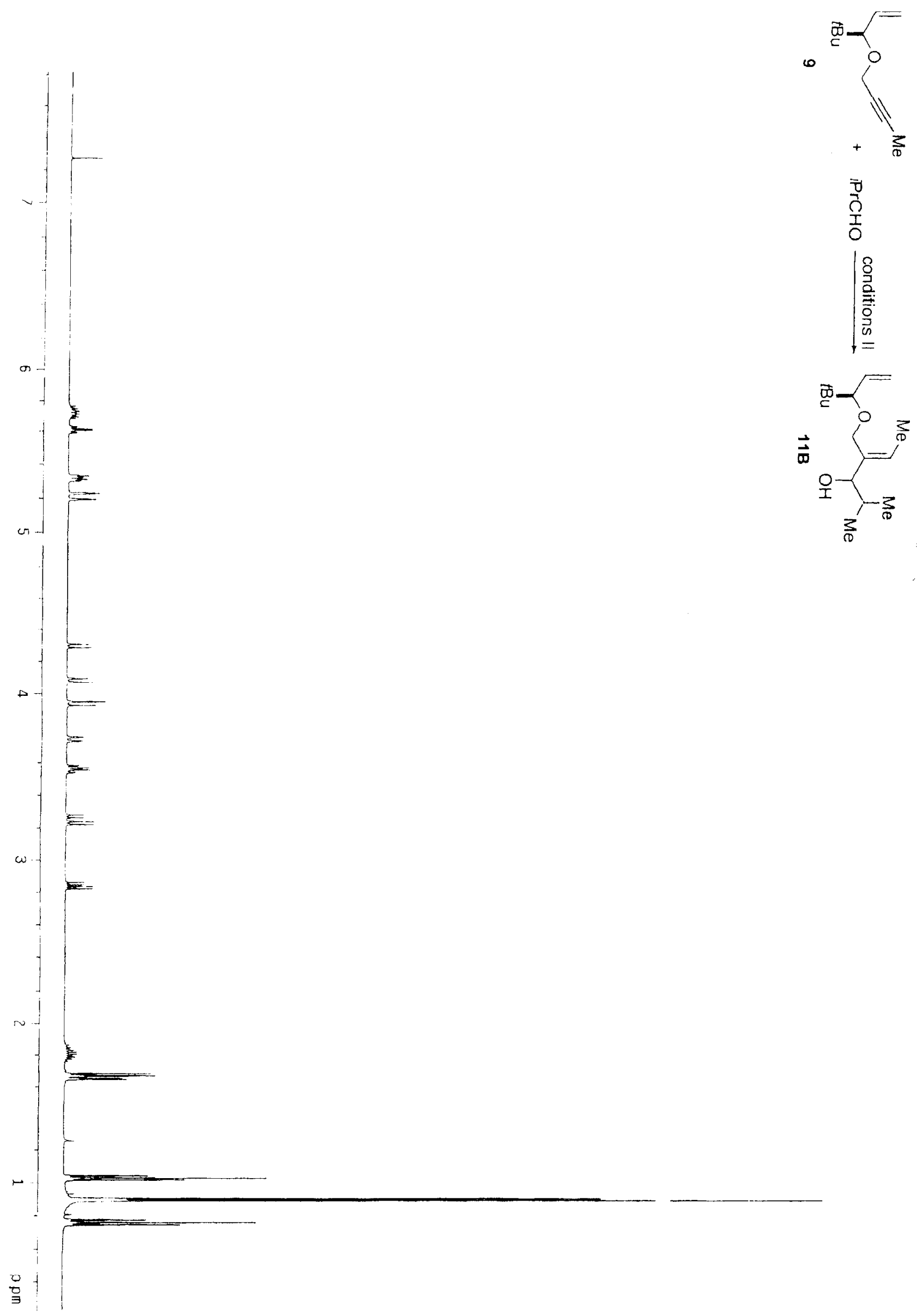




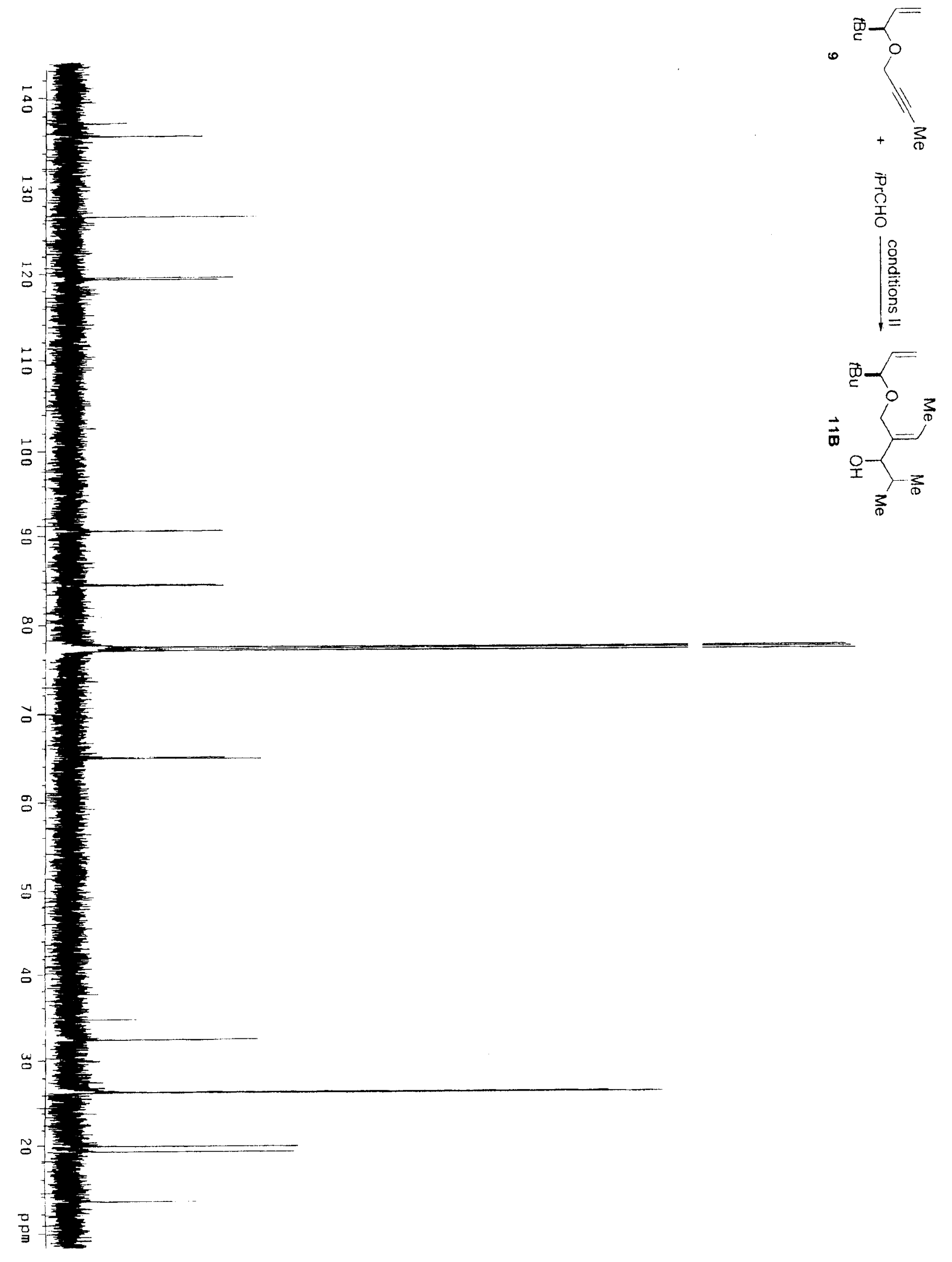




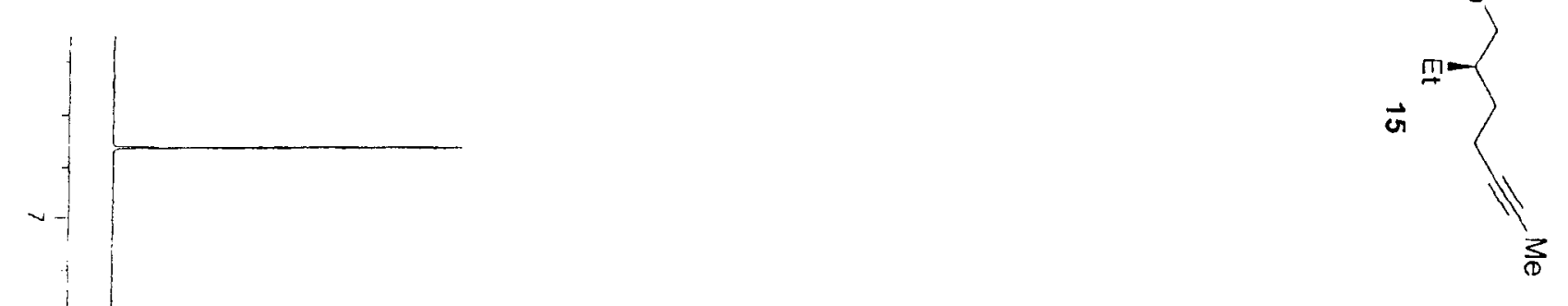

o

a

a
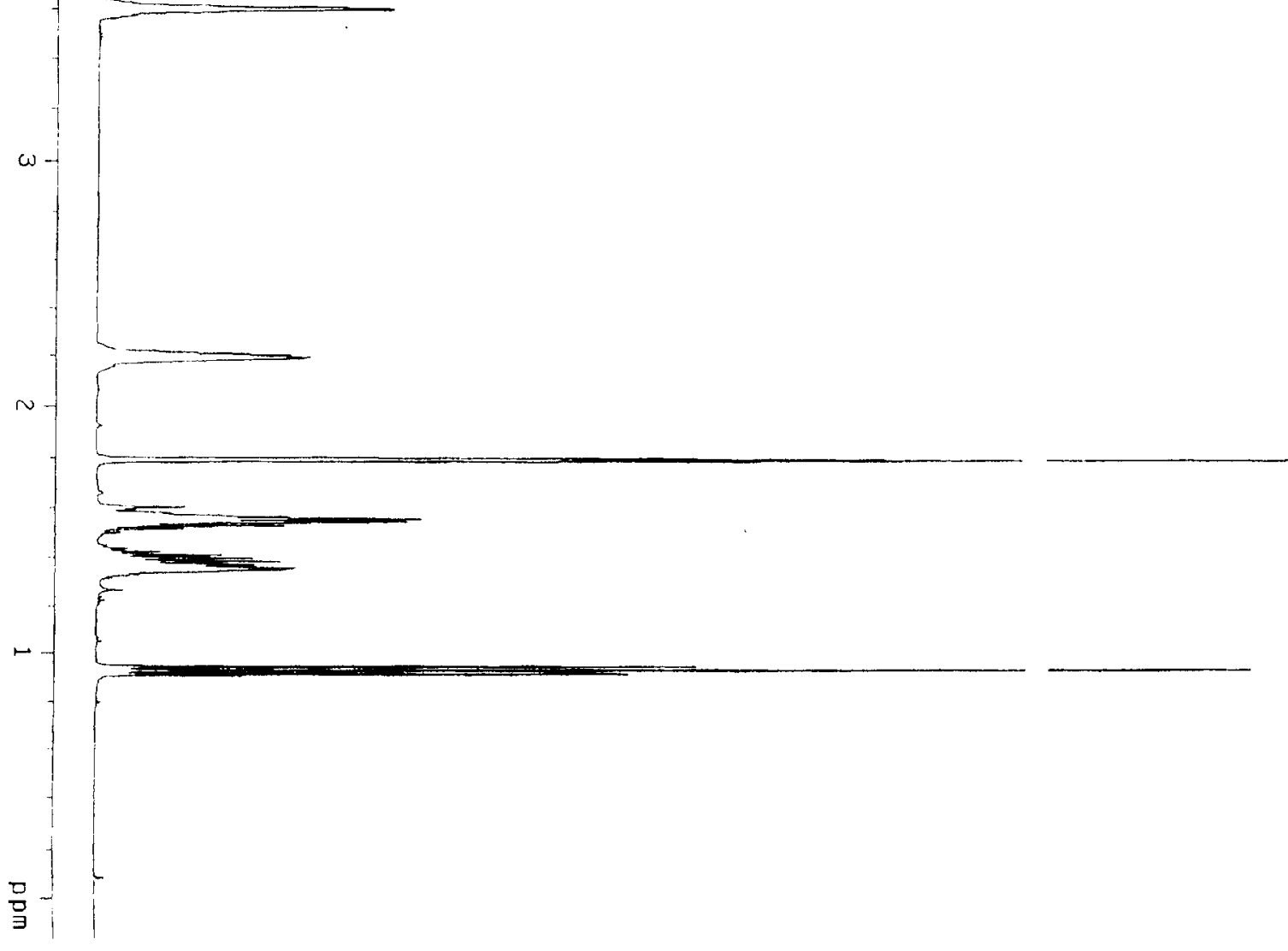


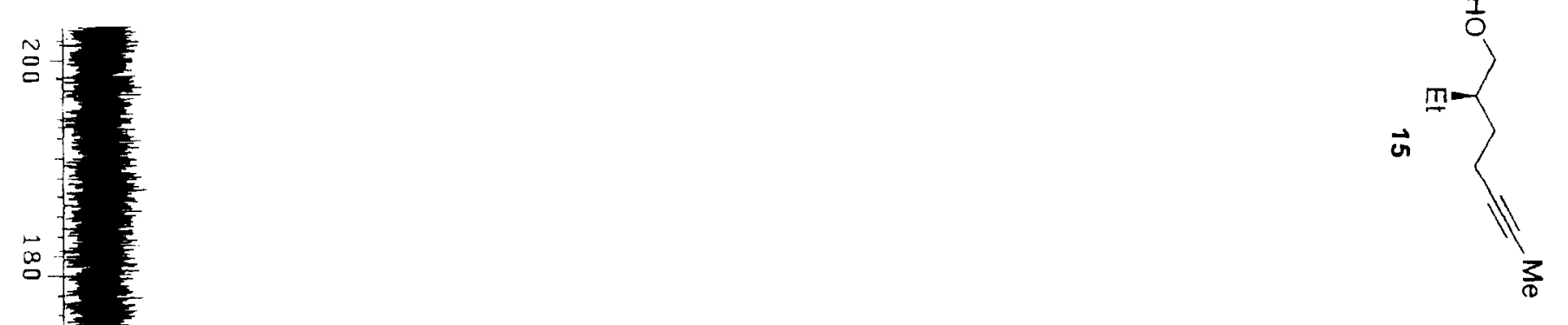

$\stackrel{2}{\circ}$

N

要

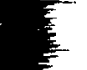

章
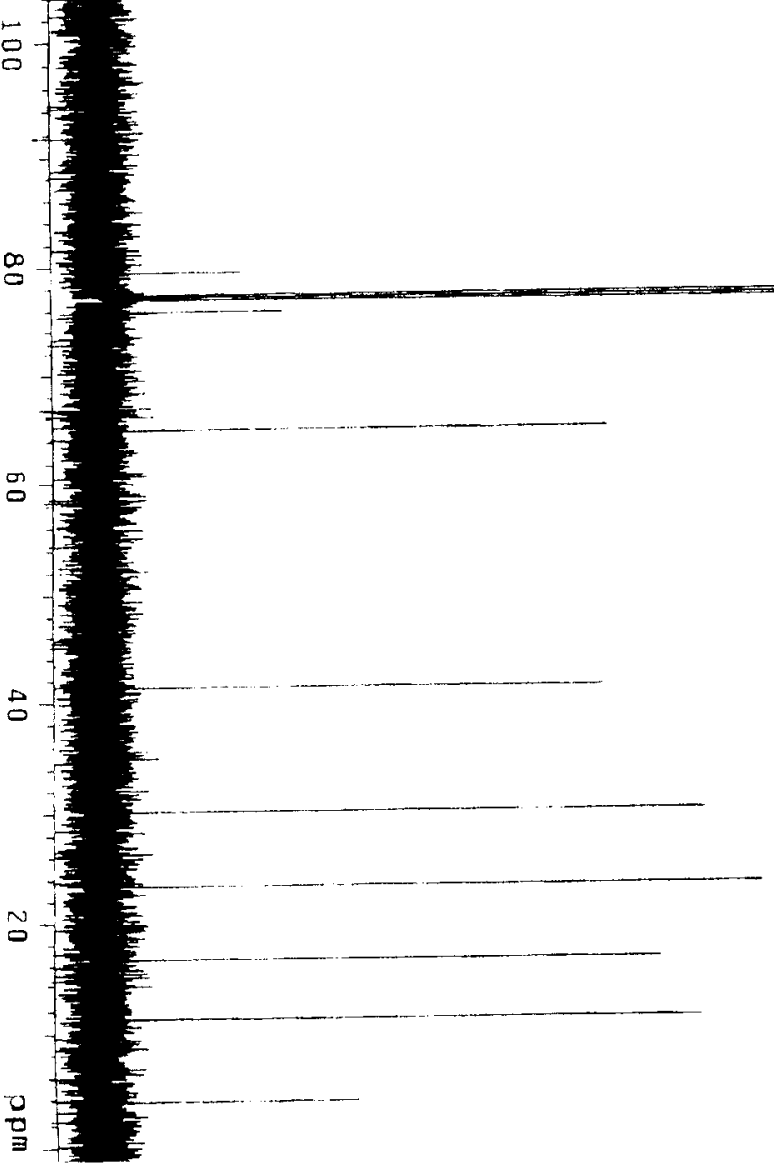


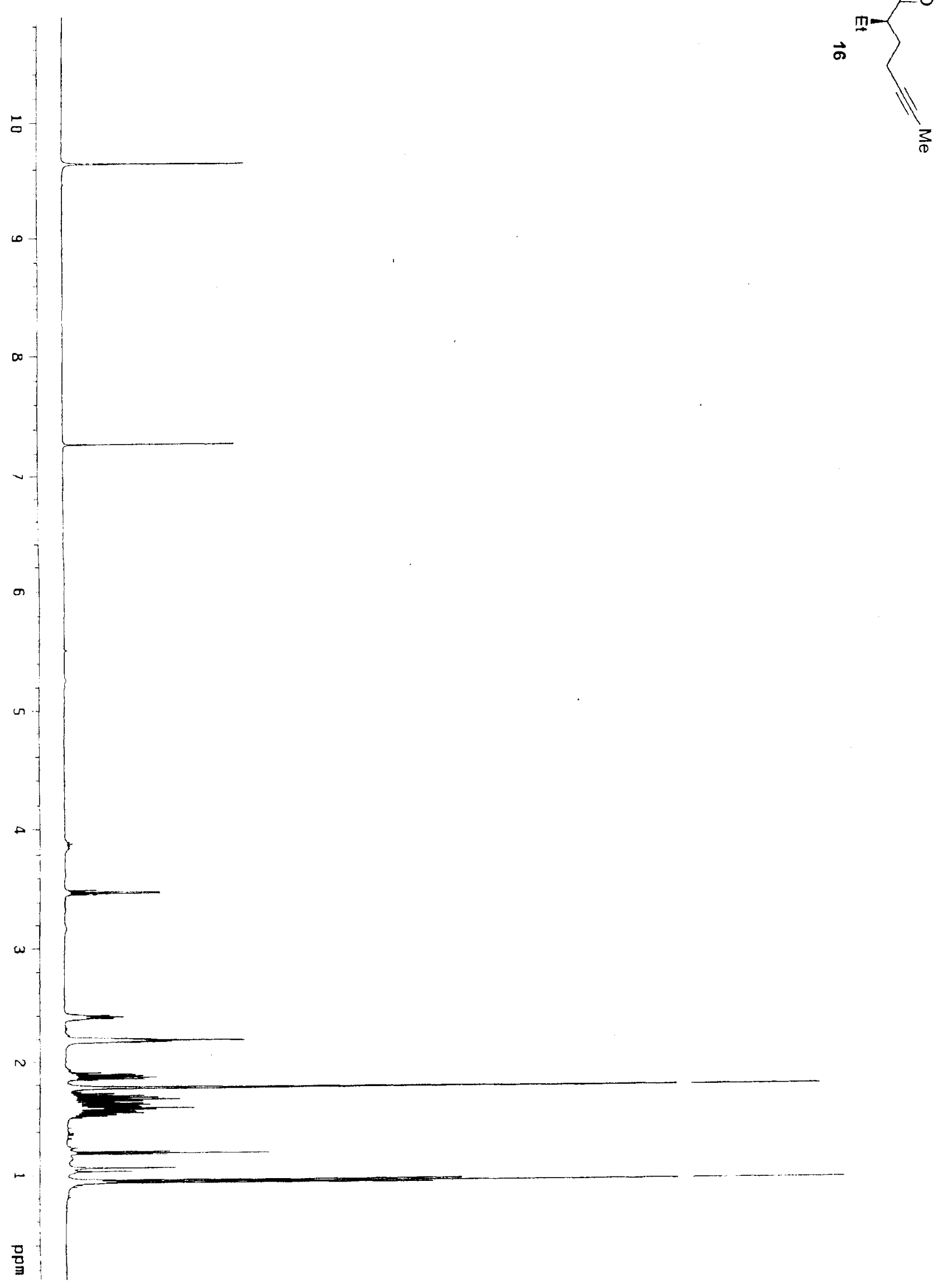




$$
\mid
$$




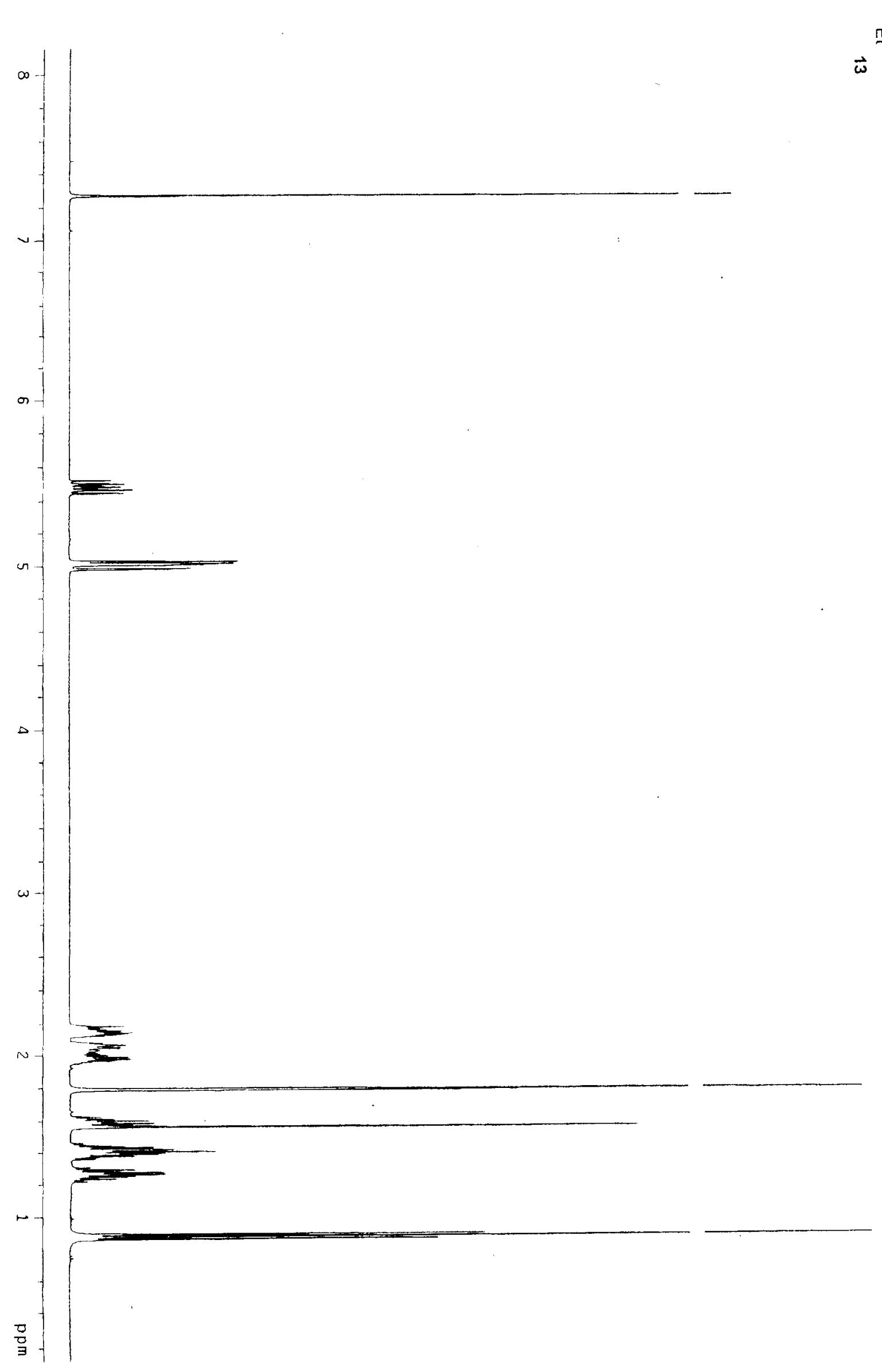



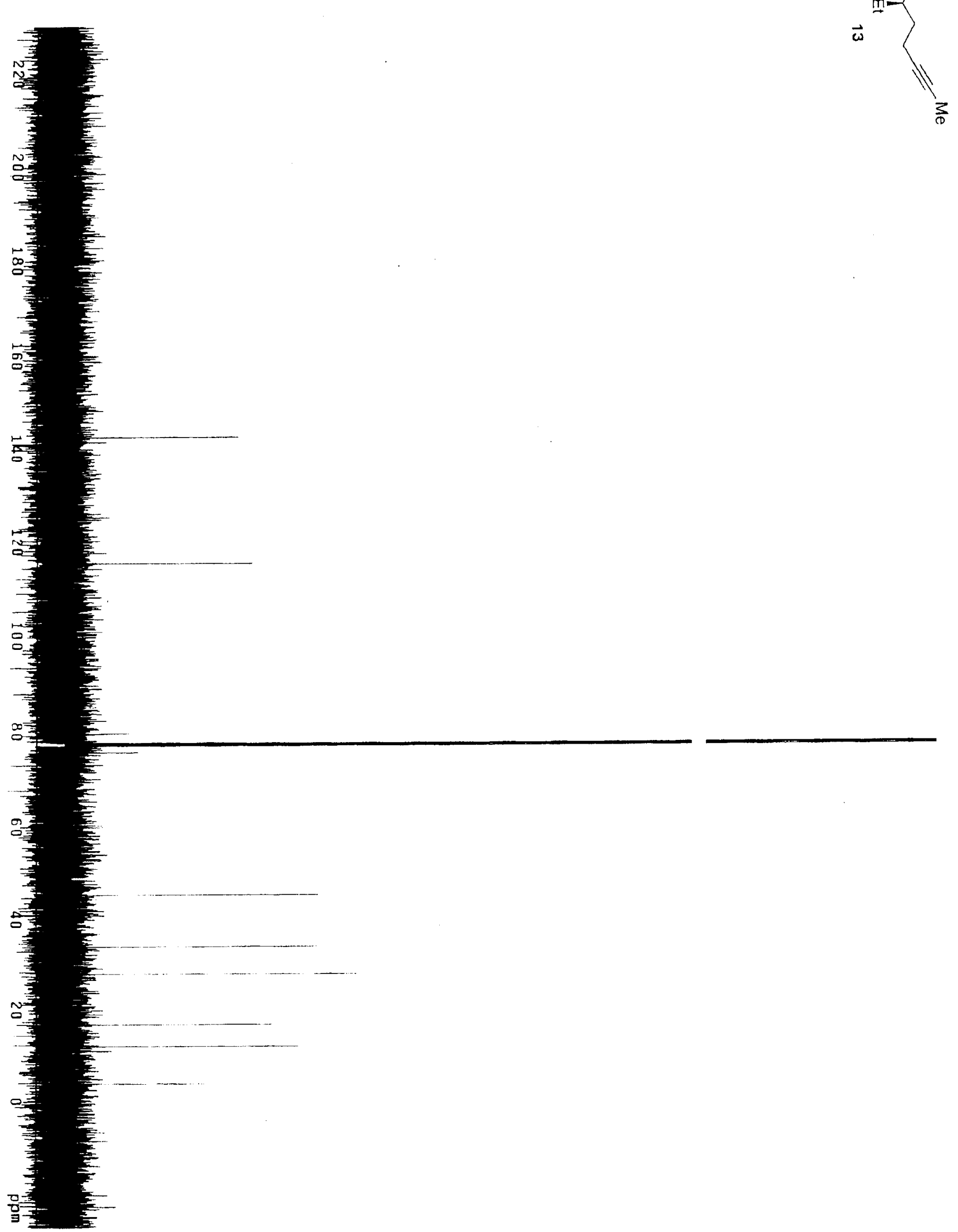


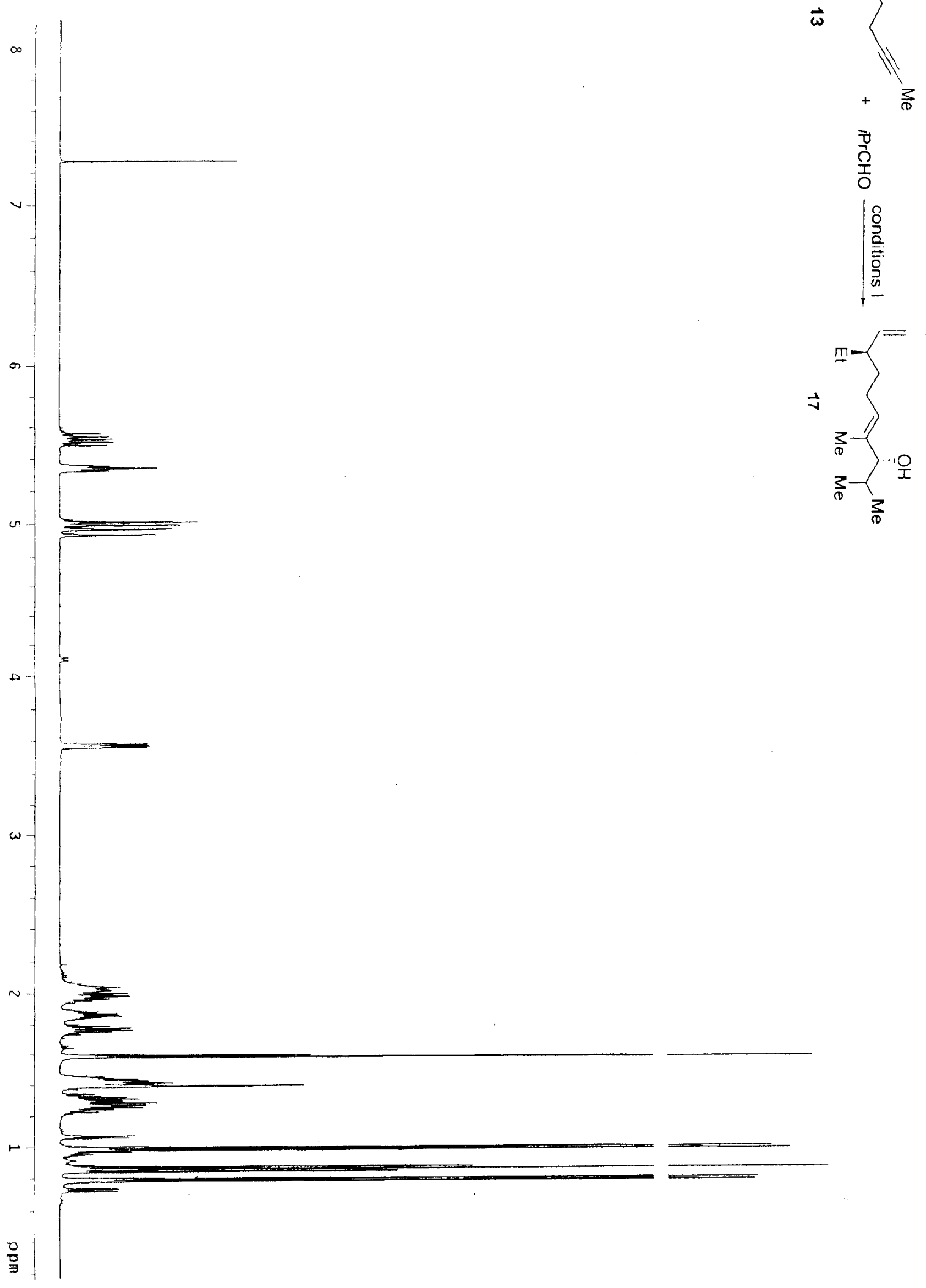



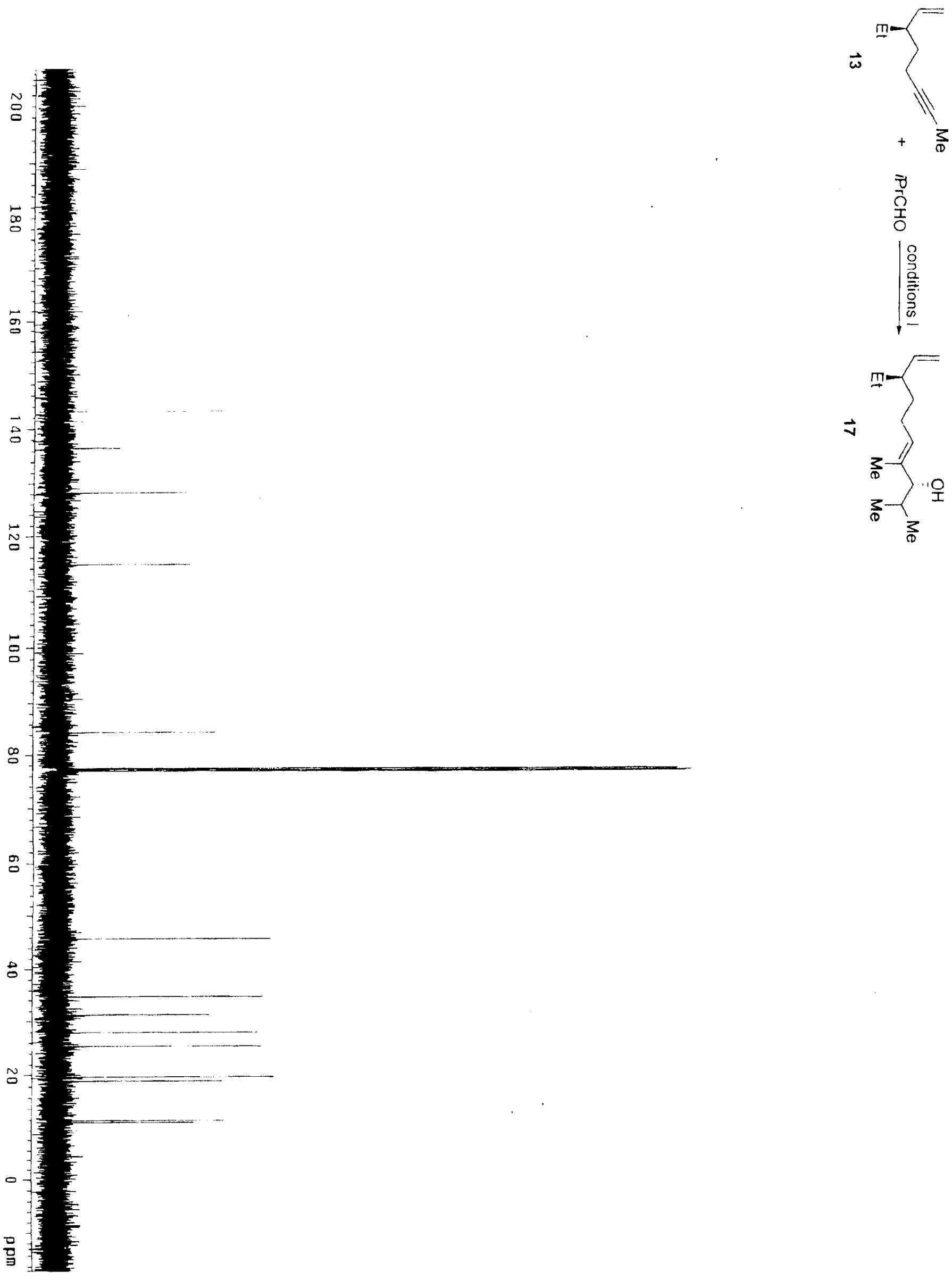